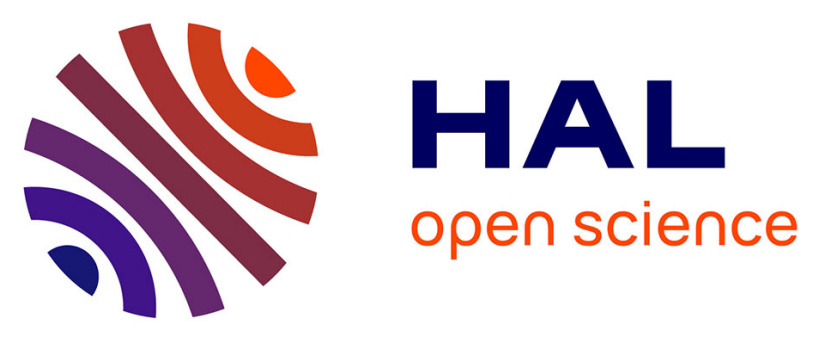

\title{
High Brightness and Easy Color Modulation in Lanthanide-Based Coordination Polymers with 5-Methoxyisophthalate as Ligand: Toward Emission Colors Additive Strategy
}

Insa Badiane, Stéphane Freslon, Yan Suffren, Carole Daiguebonne, Guillaume Calvez, Kevin Bernot, Magatte Camara, Olivier Guillou

\section{To cite this version:}

Insa Badiane, Stéphane Freslon, Yan Suffren, Carole Daiguebonne, Guillaume Calvez, et al.. High Brightness and Easy Color Modulation in Lanthanide-Based Coordination Polymers with 5Methoxyisophthalate as Ligand: Toward Emission Colors Additive Strategy. Crystal Growth \& Design, 2017, 17 (3), pp.1224-1234. 10.1021/acs.cgd.6b01607 . hal-01485636

\author{
HAL Id: hal-01485636 \\ https://hal.science/hal-01485636
}

Submitted on 4 Jul 2017

HAL is a multi-disciplinary open access archive for the deposit and dissemination of scientific research documents, whether they are published or not. The documents may come from teaching and research institutions in France or abroad, or from public or private research centers.
L'archive ouverte pluridisciplinaire HAL, est destinée au dépôt et à la diffusion de documents scientifiques de niveau recherche, publiés ou non, émanant des établissements d'enseignement et de recherche français ou étrangers, des laboratoires publics ou privés. 


\section{High brightness and easy color modulation in lanthanide- based coordination polymers with 5 -methoxy-isophthalate as ligand: Toward emission colors additive strategy}

Insa Badiane ${ }^{\mathrm{a}, \mathrm{b}}$, Stéphane Freslon ${ }^{\mathrm{a}}$, Yan Suffren $^{\mathrm{a}}$, Carole Daiguebonne ${ }^{\mathrm{a} *}$, Guillaume Calvez ${ }^{\mathrm{a}}$, Kevin Bernot ${ }^{\mathrm{a}}$, Magatte Camara ${ }^{\mathrm{b}}$ and Olivier Guillou ${ }^{\mathrm{a} *}$.

a INSA Rennes, UMR 6226 "Institut des Sciences Chimiques de Rennes", 20 Avenue des buttes de Coësmes, F35708 Rennes

${ }^{\mathrm{b}}$ Université Assane Seck de Ziguinchor, LCPM - Groupe "Matériaux Inorganiques: Chimie Douce et Cristallographie". BP. 523 Ziguinchor - Sénégal

* To whom correspondence should be addressed. 


\begin{abstract}
Reactions in water between lanthanide chlorides and the di-sodium salt of 5-methoxyisophtalic acid, $\mathrm{Na}_{2}$ (mip) $\cdot 7 \mathrm{H}_{2} \mathrm{O}$, lead to the first three series of lanthanide-based coordination polymers based on this ligand. The first series contains only one compound with chemical formula $\left[\mathrm{Ce}(\mathrm{mip})_{3 / 2}\left(\mathrm{H}_{2} \mathrm{O}\right)_{5} \cdot 2 \mathrm{H}_{2} \mathrm{O}\right]_{\infty}$. The second series has general chemical formula $\left[\mathrm{Ln}(\operatorname{mip})(\mathrm{Hmip})\left(\mathrm{H}_{2} \mathrm{O}\right)_{5} \cdot \mathrm{H}_{2} \mathrm{O}\right]_{\infty}$ with $\mathrm{Ln}=\mathrm{La}-\mathrm{Ce}$. The last family is constituted by compounds with general chemical formula $\left[\mathrm{Ln}_{2}(\operatorname{mip})_{3}\left(\mathrm{H}_{2} \mathrm{O}\right)_{8} \cdot 4 \mathrm{H}_{2} \mathrm{O}\right]_{\infty}$ with $\mathrm{Ln}=\mathrm{Sm}-$ Er plus Y. Luminescent properties of the compounds that belongs to this family have been studied. The Tb-based compound presents one of the brightest luminescence reported to date for a lanthanide-based coordination polymer. The weak intermetallic energy transfer evidenced on the third family of compounds allows easy and predictable color modulation of the hetero-bimetallic powders through additive colors strategy.
\end{abstract}

\title{
KEYWORDS
}

Lanthanide $\bullet$ Coordination polymer $\bullet$ Crystal structure $\bullet$ Luminescence $\bullet$ Energy Transfer 


\section{INTRODUCTION.}

Lanthanide-based coordination polymers have attracted great interest in the last two decades because of their potentially interesting porosity, ${ }^{[1-9]}$ magnetic ${ }^{[10-13]}$ or optical ${ }^{[14-22]}$ properties for example. More recently, lanthanide-based coordination polymers have proved their interest as taggants for fight against counterfeiting ${ }^{[23]}$ because they can present highly flexible luminescence. ${ }^{[24,25]}$ Some of us are engaged in the synthesis and study of lanthanidebased coordination polymers for more than twenty years ${ }^{[26]}$ mainly focusing their attention on benzene-poly-carboxylate ligands. ${ }^{[27]}$ In recent years we have studied several series with isophthalate derivatives as ligands ${ }^{[28-32]}$ (See Scheme 1).

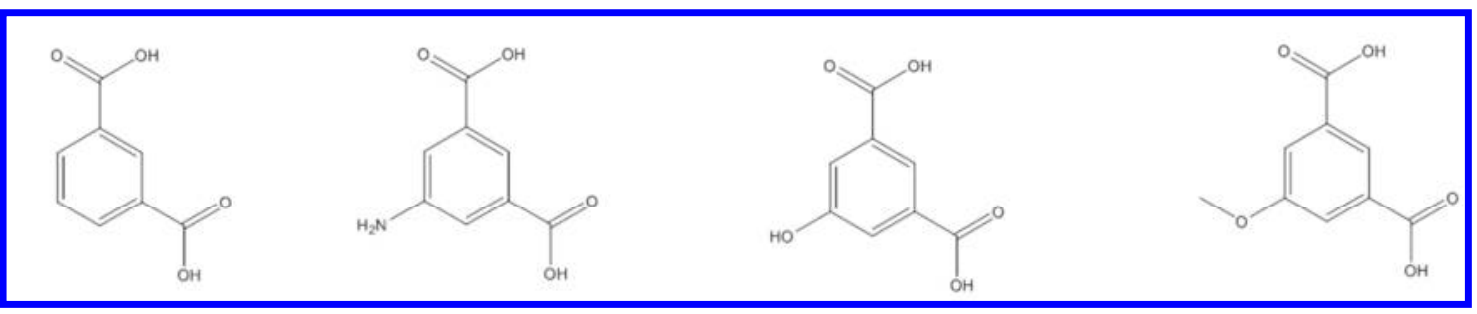

Scheme 1. From left to right, schematic representation of the ligand that have been investigated by our group: isophthalic acid $\left(\mathrm{H}_{2} \mathrm{ip}\right),{ }^{[32]}$ 5-amino-isophthalic acid $\left(\mathrm{H}_{2}\right.$ aip $\left.),{ }^{[28,}, 31\right]$ 5-hydroxy-isophthalic acid $\left(\mathrm{H}_{2} \mathrm{Oip}\right)^{[30]}$ and 5-methoxy-isophthalic acid $\left(\mathrm{H}_{2} \mathrm{mip}\right)$ (This work).

These series that present almost isoreticular crystal structures (Figure 1) exhibit promising optical properties that arise from competing transfers (ligand-to-metal and metalto-metal energy transfers, photo-induced electron transfer...). These promising optical properties have encouraged us to undertake the study of lanthanide-based coordination polymers with 5-methoxy-isophthalate ligand hereafter referred as (mip) ${ }^{2-}$. 


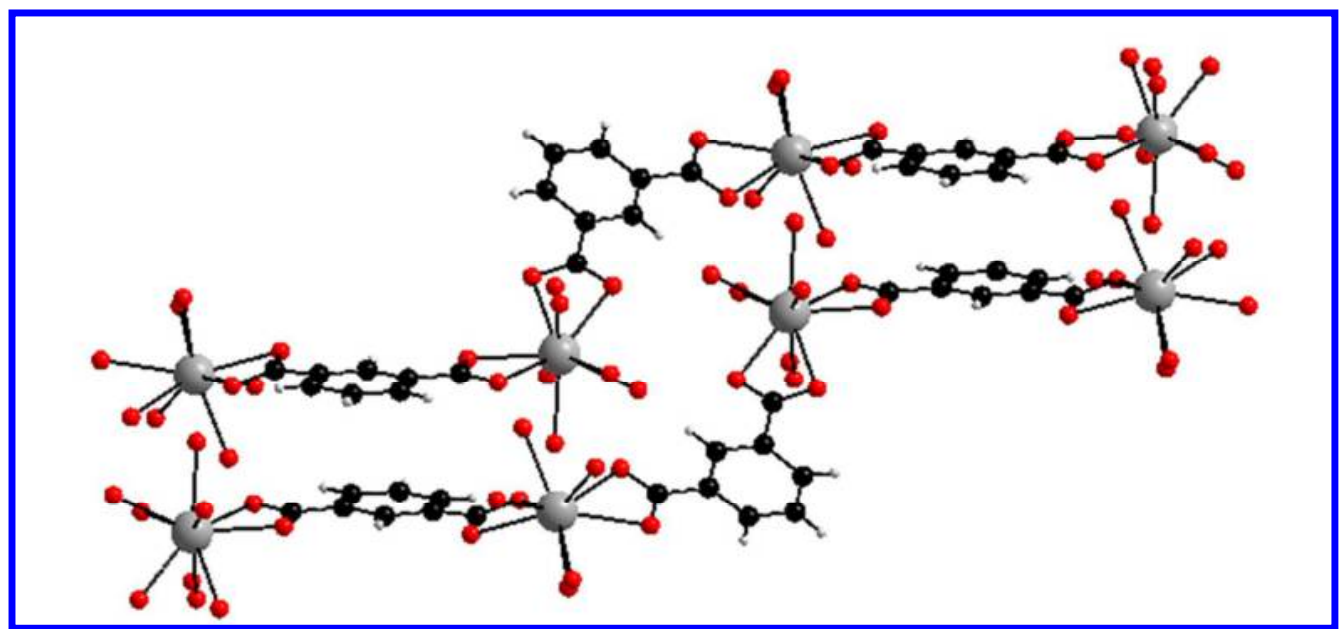

Figure 1. Projection view of a zig-zag double-chains molecular motif of $\left[\mathrm{Gd}_{2}(\mathrm{ip})_{3}\left(\mathrm{H}_{2} \mathrm{O}\right)_{9} \cdot 6 \mathrm{H}_{2} \mathrm{O}\right]_{\infty}$. Redrawn from reference [32]. This molecular motif is also encountered in crystal structures of 5-amino-isophthalate- and 5-hydroxy-isophthalate-based lanthanide coordination polymers. ${ }^{[28,30,31]}$

To the best of our knowledge, some coordination polymers based on (mip) ${ }^{2-}$ ligand and involving transition metal ions have recently been reported ${ }^{[33-35]}$ but, to date, none of them involves lanthanide ions. We want to report here the first three series of lanthanide-containing coordination polymers based on this ligand.

\section{EXPERIMENTAL SECTION.}

\section{Synthesis and characterization of the ligand.}

5-methoxy-isophthalic acid has been purchased from TCI (98\%) and used without further purification. Two equivalents of sodium hydroxide are added to an aqueous suspension of 5-methoxy-isophthalic acid. The obtained clear solution is then evaporated to dryness and the residual solid is dissolved in ethanol and refluxed for one hour. Then precipitation is provoked by addition of an excess of ethoxy-ethane. The white precipitate is filtered and washed with ethoxy-ethane. After re-crystallization in deionized water, the powder is filtered and dried under ambient conditions. The yield is about $90 \%$. Re- 
crystallization has provided single crystals suitable for X-ray structure determination (Figure 2). Selected crystal and final structure refinement data are listed in Table 1.

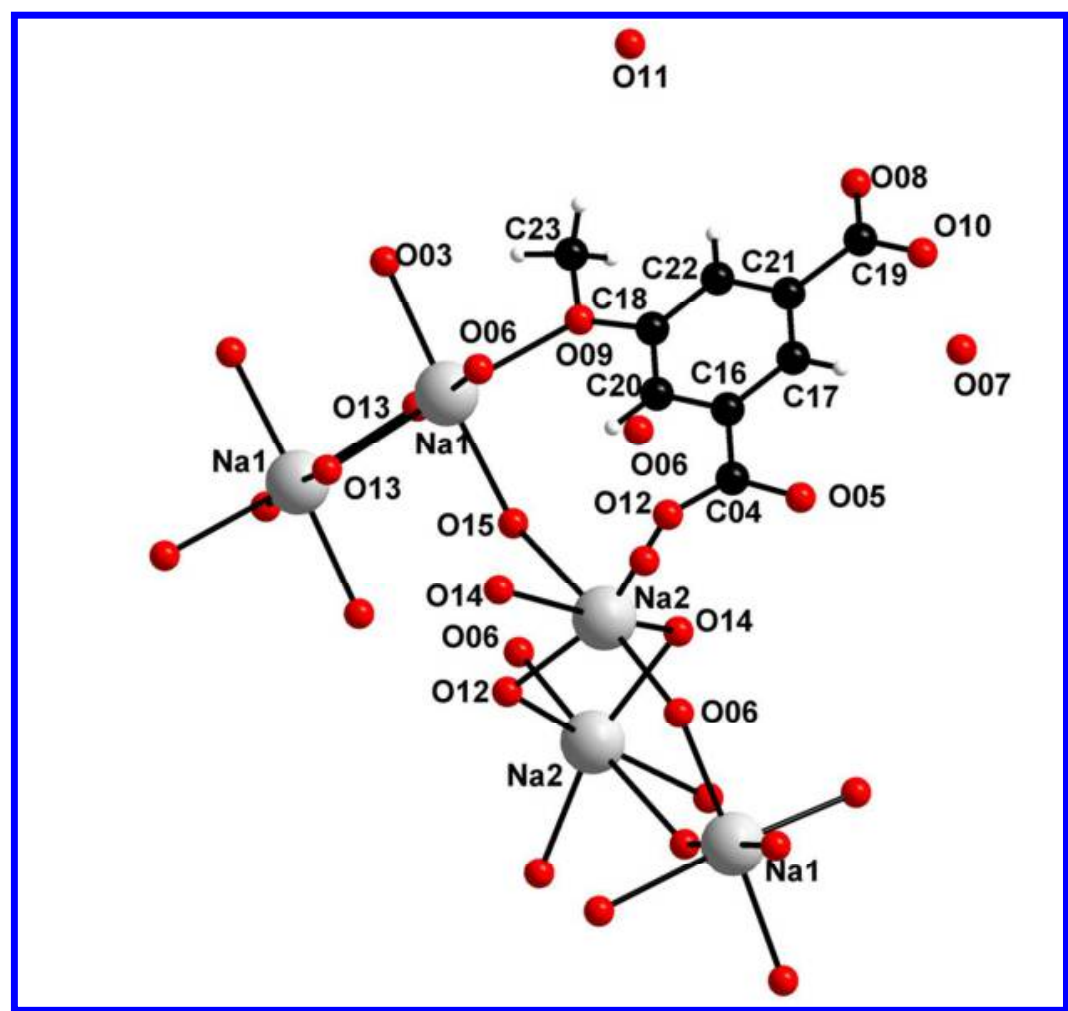

Figure 2. Projection view of an extended asymmetric unit of $\mathrm{Na}_{2}(\mathrm{mip}) \cdot 7 \mathrm{H}_{2} \mathrm{O}$.

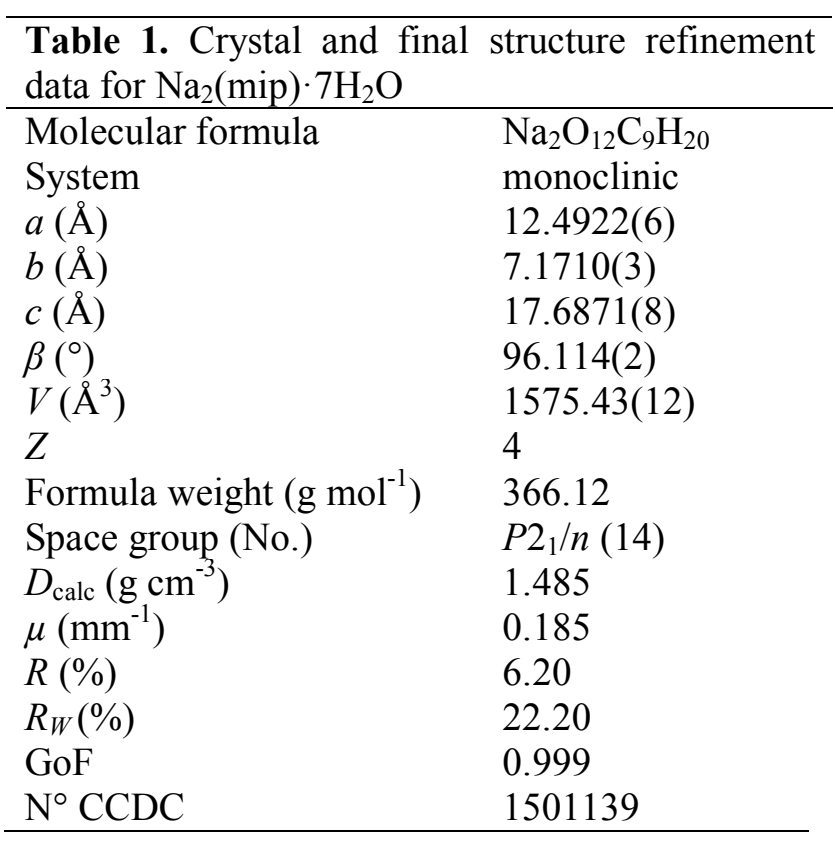


Powder X-ray diffraction pattern indicates that the powder and the single crystal are isostructural (Figure S1). Chemical analysis for $\mathrm{Na}_{2} \mathrm{C}_{9} \mathrm{H}_{20} \mathrm{O}_{12}\left(\mathrm{MW}=366 \mathrm{~g} \cdot \mathrm{mol}^{-1}\right)$ found (calc.): Na 12.4\% (12.5\%); C 29.4\% (29.5\%); H 5.6\% (5.5\%); O 52.6\% (52.5\%).

IR spectrum does not show any characteristic band of protonated carboxylate functions $\left(1410 \mathrm{~cm}^{-1}\right)$. Thermal analyses confirm the departure of 7 water molecules (Exp. 34.0\%; Calc. 34.4\%). First, there is a first weight loss between $50^{\circ} \mathrm{C}$ and $150^{\circ} \mathrm{C}$ that correspond to six water molecules (Exp. 29.3\%; Calc. 29.5\%). The seventh one is removed between $150^{\circ} \mathrm{C}$ and $200^{\circ} \mathrm{C}$ (Exp. $4.7 \%$; Calc. 4.9\%). This assumption is supported by IR spectra of the exhausted gas that have been recorded all along the thermal analysis (Figure $\mathrm{S} 2)$. Liquid UV-visible absorption spectrum of a diluted aqueous solution $\left(2.7310^{-4} \mathrm{~mol}^{-\mathrm{L}^{-1}}\right)$ of $\mathrm{Na}_{2}$ (mip) $\cdot 7 \mathrm{H}_{2} \mathrm{O}$ present a maximum at $299 \mathrm{~nm}$ with $\varepsilon_{299}=4320 \mathrm{~L} \cdot \mathrm{mol}^{-1} \cdot \mathrm{cm}^{-1}$ (Figure S3).

\section{Synthesis and characterization of the coordination polymers as single crystals.}

Lanthanide oxides $(99.99 \%)$ were purchased from the AMPERE company. The chlorides were prepared according to literature procedures. ${ }^{[36]}$ Tetramethylorthosilicate (TMOS) and agarose gels were purchased from Acros Organics and used without further purification. They were jellified according to established procedures. ${ }^{[37-39]}$ Dilute aqueous solutions $\left(0.1\right.$ mol. $\left.\mathrm{L}^{-1}\right)$ of the lanthanide chloride on one hand and of the di-sodium salt of methoxy-isophtalate on the other hand were allowed to slowly diffuse through a gel bridge in U-shaped tubes. After a few weeks, single crystals suitable for X-ray structure determination were obtained (See Figure 3 for an example).

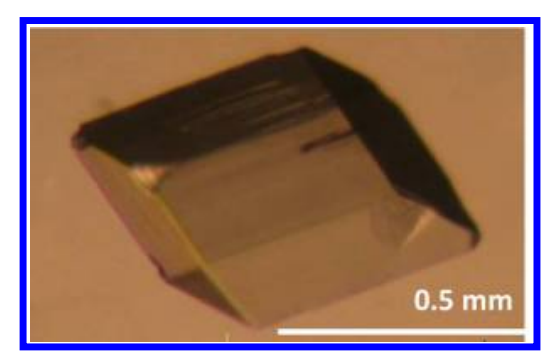


Figure 3. Picture of a single crystal of $\left[\mathrm{La}(\operatorname{mip})(\mathrm{Hmip})\left(\mathrm{H}_{2} \mathrm{O}\right)_{5} \cdot \mathrm{H}_{2} \mathrm{O}\right]_{\infty}$.

Three types of crystal structures were identified depending on the involved lanthanide ion. Results are summarized in Table 2.

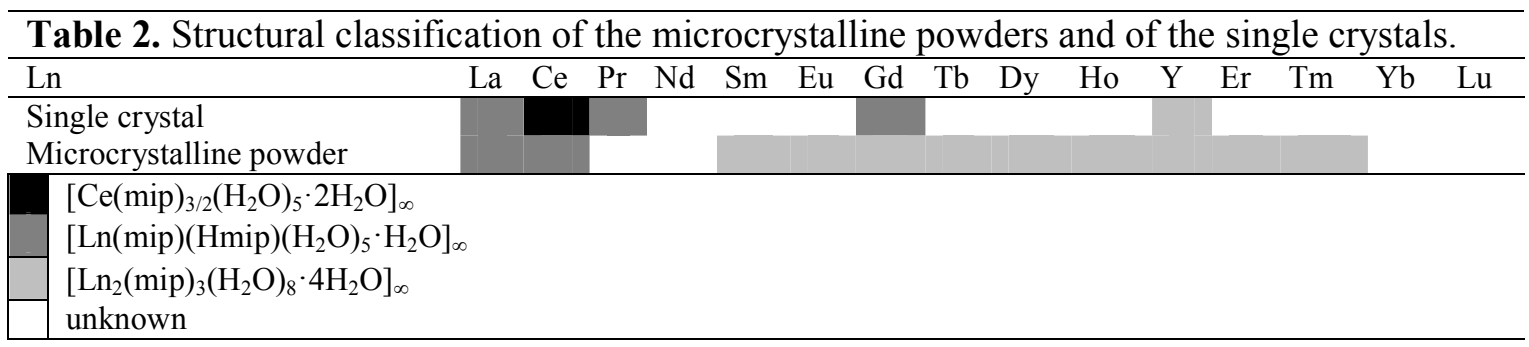

\section{Synthesis and characterization of the coordination polymers as microcrystalline powders.}

Microcrystalline powders of the coordination polymers were obtained by mixing stoichiometric aqueous solutions of a lanthanide chloride $(1 \mathrm{mmol}$ in $20 \mathrm{~mL}$ of deionized water) and of di-sodium methoxy-isophthalate $(1.5 \mathrm{mmol}$ in $20 \mathrm{~mL}$ of deionized water). Precipitations immediately occurred. Microcrystalline powders were filtered and dried in air. Yields are closed to $90 \%$. Chemical analyses of the microcrystalline powders are listed in Table S1. On the basis of their powder X-ray diffraction diagrams, microcrystalline powders were classified in two series (See Figures S4 and S5): The first series contains the compounds that have been obtained with lanthanum or cerium while the second one contains compounds obtained with one of the lanthanide ion comprised between samarium and ytterbium plus yttrium. Other lanthanide ions lead to amorphous powders. Compounds that belong to the first family are isomorphous to $\left[\mathrm{Gd}(\mathrm{mip})(\mathrm{Hmip})\left(\mathrm{H}_{2} \mathrm{O}\right)_{5} \cdot \mathrm{H}_{2} \mathrm{O}\right]_{\infty}$ and those that belong to the second family are isomorphous to $\left[\mathrm{Y}_{2}(\mathrm{mip})_{3}\left(\mathrm{H}_{2} \mathrm{O}\right)_{8} \cdot 4 \mathrm{H}_{2} \mathrm{O}\right]_{\infty}$. Both crystal structures are described hereafter. It can be noticed that no microcrystalline powder present a powder X-ray diffraction diagram that corresponds to $\left[\mathrm{Ce}(\mathrm{mip})_{3 / 2}\left(\mathrm{H}_{2} \mathrm{O}\right)_{5} \cdot 2 \mathrm{H}_{2} \mathrm{O}\right]_{\infty}($ Table2). 


\section{Single crystal X-ray diffraction.}

Single crystals of $\mathrm{Na}_{2}(\mathrm{mip}) \cdot 7 \mathrm{H}_{2} \mathrm{O}$ and of $\left.[\mathrm{Gd}(\mathrm{mip})(\mathrm{Hmip})]\left(\mathrm{H}_{2} \mathrm{O}\right)_{5} \cdot \mathrm{H}_{2} \mathrm{O}\right]_{\infty}$ were mounted on a APEXII AXS-Bruker diffractometer (150K) with Mo K $\alpha$ radiation $(\lambda=$ $0.71073 \AA)$ and single crystal of $\left[\mathrm{Y}_{2}(\operatorname{mip})_{3}\left(\mathrm{H}_{2} \mathrm{O}\right)_{8} \cdot 4 \mathrm{H}_{2} \mathrm{O}\right]_{\infty}$ and $\left[\mathrm{Ce}(\operatorname{mip})_{3 / 2}\left(\mathrm{H}_{2} \mathrm{O}\right)_{5} \cdot 2 \mathrm{H}_{2} \mathrm{O}\right]_{\infty}$ on a D8Venture Bruker AXS diffractometer with multilayers monochromatized Mo Ka radiation and equipped with a CMOS PHOTON100 detector (300K). Data reduction and cell refinement were performed with Denzo and Scalepack programs ${ }^{[40]}$ or Apex3(2015), Saint(V8.37a) and $\operatorname{Sadabs}(2014 / 5)^{[41-43]}$ according to the used diffractometer. The crystal structures have been solved by direct methods using SIR97 program, ${ }^{[44]}$ and refined with full matrix least-square methods based on $\mathrm{F}^{2}$ (SHELX97 ${ }^{[45]}$ ) with WINGX program. ${ }^{[46]}$ All nonhydrogen atoms were refined anisotropically using SHELXL program. Hydrogen atoms bound to the organic ligand were located at ideal positions except those bound to the disordered ligand in the crystal structure of $\left[\mathrm{Ce}(\mathrm{mip})_{3 / 2}\left(\mathrm{H}_{2} \mathrm{O}\right)_{5} \cdot 2 \mathrm{H}_{2} \mathrm{O}\right]_{\infty}$ that have not been located. Hydrogen atoms of the water molecules were not located. Crystal and final structure refinement data of $\mathrm{Na}_{2}(\mathrm{mip}) \cdot 7 \mathrm{H}_{2} \mathrm{O}$ are listed in Table 1 and those of $\left.\left[\mathrm{Ce}(\operatorname{mip})_{3 / 2}\left(\mathrm{H}_{2} \mathrm{O}\right)_{5} \cdot 2 \mathrm{H}_{2} \mathrm{O}\right]_{\infty},[\mathrm{Gd}(\operatorname{mip})(\mathrm{Hmip})]\left(\mathrm{H}_{2} \mathrm{O}\right)_{5} \cdot \mathrm{H}_{2} \mathrm{O}\right]_{\infty}$ and of $\left[\mathrm{Y}_{2}(\operatorname{mip})_{3}\left(\mathrm{H}_{2} \mathrm{O}\right)_{8} \cdot 4 \mathrm{H}_{2} \mathrm{O}\right]_{\infty}$ in Table 3. Full details of the X-ray structure determination of the four crystal structures have been deposited with the Cambridge Crystallographic Data Center under the depository numbers CCDC-1501139 $\left(\mathrm{Na}_{2}(\mathrm{mip}) \cdot 7 \mathrm{H}_{2} \mathrm{O}\right), \mathrm{CCDC}-1505544\left(\left[\mathrm{Ce}(\mathrm{mip})_{3 / 2}\left(\mathrm{H}_{2} \mathrm{O}\right)_{5} \cdot 2 \mathrm{H}_{2} \mathrm{O}\right]_{\infty}\right)$, CCDC-1501131 ([Gd(mip) $\left.\left(\mathrm{H}(\operatorname{mip})\left(\mathrm{H}_{2} \mathrm{O}\right)_{5} \cdot \mathrm{H}_{2} \mathrm{O}\right]_{\infty}\right) \quad$ and $\quad$ CCDC-1501130 $\left(\left[\mathrm{Y}_{2}(\mathrm{mip})_{3}\left(\mathrm{H}_{2} \mathrm{O}\right)_{8} \cdot 4 \mathrm{H}_{2} \mathrm{O}\right]_{\infty}\right)$. They can be obtained free of charge at http://www.ccdc.cam.ac.uk/conts/retrieving.html [or from the Cambridge Crystallographic Data Centre, 12, Union Road, Cambridge CB2 IEZ, UK; fax: (internat.) +44-1223/336-033; E-mail: deposit@ccdc.cam.ac.uk], on request, from the authors and the reference to this publication. 
Table 3. Crystal and final structure refinement data for $\left[\mathrm{Ce}(\mathrm{mip})_{3 / 2}\left(\mathrm{H}_{2} \mathrm{O}\right)_{5} \cdot 2 \mathrm{H}_{2} \mathrm{O}\right]_{\infty}$, $\left[\mathrm{Gd}(\mathrm{mip})(\mathrm{Hmip})\left(\mathrm{H}_{2} \mathrm{O}\right)_{5} \cdot \mathrm{H}_{2} \mathrm{O}\right]_{\infty}$ and $\left[\mathrm{Y}_{2}(\operatorname{mip})_{3}\left(\mathrm{H}_{2} \mathrm{O}\right)_{8} \cdot 4 \mathrm{H}_{2} \mathrm{O}\right]_{\infty}$.

\begin{tabular}{|c|c|c|c|}
\hline Molecular formula & $\mathrm{Ce}_{2} \mathrm{C}_{27} \mathrm{H}_{46} \mathrm{O}_{29}$ & $\mathrm{GdO}_{16} \mathrm{C}_{18} \mathrm{H}_{25}$ & $\mathrm{Y}_{2} \mathrm{O}_{27} \mathrm{C}_{27} \mathrm{H}_{18}$ \\
\hline System & monoclinic & triclinic & monoclinic \\
\hline$a(\AA)$ & $10.8750(2)$ & $7.4437(3)$ & $17.4214(11)$ \\
\hline$b(\AA)$ & $10.6070(1)$ & $10.9493(4)$ & $10.7884(8)$ \\
\hline$c(\AA)$ & $18.4790(2)$ & $14.5247(6)$ & $20.3688(15)$ \\
\hline$\alpha\left(^{\circ}\right)$ & - & $89.238(2)$ & - \\
\hline$\beta\left(^{\circ}\right)$ & $100.700(1)$ & $83.423(2)$ & $104.136(2)$ \\
\hline$\gamma\left({ }^{\circ}\right)$ & - & $78.619(2)$ & - \\
\hline$V\left(\AA^{3}\right)$ & $2094.51(1)$ & $1152.84(8)$ & $3712.4(5)$ \\
\hline$Z$ & 2 & 2 & 4 \\
\hline Formula weight $\left(\mathrm{g} \cdot \mathrm{mol}^{-1}\right)$ & 1114.88 & 654.53 & 952.23 \\
\hline Space group (No.) & $P 2_{1} / c(14)$ & $P-1(2)$ & $P 2_{1} / n(14)$ \\
\hline$D_{\text {calc }}\left(\right.$ g.cm $\left.\mathrm{cm}^{-3}\right)$ & 1.768 & 1.851 & 1.704 \\
\hline$\mu\left(\mathrm{mm}^{-1}\right)$ & 2.242 & 2.955 & 3.211 \\
\hline$R(\%)$ & 5.14 & 2.86 & 3.33 \\
\hline$R_{W}(\%)$ & 16.30 & 8.16 & 10.19 \\
\hline GoF & 1.083 & 1.101 & 1.055 \\
\hline $\mathrm{N}^{\circ} \mathrm{CCDC}$ & 1505544 & 1501131 & 1501130 \\
\hline
\end{tabular}

\section{Powder X-ray diffraction.}

The diagrams have been collected using a PanalyticalX'Pert Pro diffractometer equipped with an $\mathrm{X}^{\prime}$ Celerator detector. Calculated patterns were produced using POWDERCELL and WINPLOTR software programs. ${ }^{[47,48]}$

Thermal dependent X-ray diffraction diagrams have been produced with the same diffractometer. The samples are heating from room temperature to $1000^{\circ} \mathrm{C}$ using an Anton Parr HTK 1200 furnace under nitrogen atmosphere.

\section{Solid state luminescent measurements.}

Solid state emission and excitation spectra have been measured on a Horiba JobinYvon Fluorolog III fluorescence spectrometer equipped with a Xe lamp $450 \mathrm{~W}$ and a UV-Vis photomultiplier (Hamamatsu R928, sensitivity 190-860 nm). Most of the luminescence 
spectra were recorded between $350 \mathrm{~nm}$ and $725 \mathrm{~nm}$ at room temperature. The quantum yield measurements were performed using a Jobin-Yvon integrating sphere $\left(\Phi=\left(E_{c}-E_{a}\right) /\left(L_{a}-L_{c}\right)\right.$ with $E_{c}$ being the integrated emission spectrum of the sample, $E_{a}$ the integrated "blank" emission spectrum, $\mathrm{L}_{\mathrm{a}}$ the "blank" absorption and $\mathrm{L}_{\mathrm{c}}$ the sample absorption at the excitation wavelength). The emission/excitation spectra and quantum yield recordings were realized on powder samples introduced in cylindrical quartz cells of $0.7 \mathrm{~cm}$ diameter and $2.4 \mathrm{~cm}$ height, which it is placed directly inside the integrating sphere. The luminescence of the Gd-based microcrystalline powder has been measured at $77 \mathrm{~K}$, the sample is introduced in a quartz capillary tube, which it is placed inside a small Dewar containing nitrogen liquid. Luminescence decays have also been measured at room temperature using this apparatus with a Xe flash lamp (phosphorescence mode). Lifetimes and quantum yields are averages of three independent determinations. Appropriate filters were used to remove the residual excitation laser light, the Rayleigh scattered light and associated harmonics from spectra. All spectra were corrected for the instrumental response function.

Comparative solid state luminescent spectra have been measured on a Perkin-Elmer LS-55 spectrometer with a Xe flash lamp and equipped with a UV-Vis photomultiplier (Hamamatsu R928) between 450 and $725 \mathrm{~nm}$ under identical operating conditions and without turning the lamp off to ensure a valid comparison between the emission spectra. All spectra have been recorded with the phosphorescence mode, not with the standard fluorescence mode (delay and gate times are applied to remove residual light from sample holder). Automatic filters were also used during the measurements as for the Fluorolog III.

Luminescence intensities of the samples expressed in Cd. $\mathrm{m}^{-2}$ have been measured with a Gigahertz-Optik X1-1 optometer with an integration time of $200 \mathrm{~ms}$ on $1.5 \mathrm{~cm}^{2}$ pellets. The intensity of the UV flux at sample location, $0.385 \mathrm{~mW} . \mathrm{cm}^{-2}$, has been measured with a VilberLourmat VLX-3W radiometer. $\left[\mathrm{Tb}_{2}(\mathrm{bdc})_{3} \cdot 4 \mathrm{H}_{2} \mathrm{O}\right]_{\infty}$ where $\mathrm{bdc}^{2-}$ stands for terephthalate 
was used as a standard. Its luminance is $142 \mathrm{Cd} . \mathrm{m}^{-2}$ under these operating conditions $\left(\lambda_{\text {exc }}=312 \mathrm{~nm} ;\right.$ flux $\left.=0.385 \mathrm{~mW} \cdot \mathrm{cm}^{-2}\right) \cdot{ }^{[49]}$

\section{Colorimetric measurements.}

The CIE (Commission Internationale de l'Eclairage) (x,y) emission color coordinates $^{[50,}$ 51] were obtained using a MSU-003 colorimeter (Majantys) with the PhotonProbe 1.6.0 Software (Majantys). Color measurements: $2^{\circ}$, CIE 1931, step $5 \mathrm{~nm}$, under $312 \mathrm{~nm} \quad \mathrm{UV}$ light. $\mathrm{X}=k \times \int_{380 \mathrm{~nm}}^{780 \mathrm{~nm}} I_{\lambda} \times x_{\lambda}, \quad \mathrm{Y}=k \times \int_{380 \mathrm{~nm}}^{780 \mathrm{~nm}} I_{\lambda} \times y_{\lambda} \quad$ and $\quad \mathrm{Z}=k \times$ $\int_{380 \mathrm{~nm}}^{780 \mathrm{~mm}} I_{\lambda} \times z_{\lambda}$ with $\mathrm{k}$ constant for the measurement system $\mathrm{I}_{\lambda}$ sample spectrum intensity, wavelength depending, $\mathrm{x}_{\lambda}, \mathrm{y}_{\lambda}, \mathrm{z}_{\lambda}$ trichromatic values $\mathrm{x}=\mathrm{X} /(\mathrm{X}+\mathrm{Y}+\mathrm{Z}), \mathrm{y}=\mathrm{Y} /(\mathrm{X}+\mathrm{Y}+\mathrm{Z})$ and $\mathrm{z}=$ $\mathrm{Z} /(\mathrm{X}+\mathrm{Y}+\mathrm{Z})$. Mean $\mathrm{xyz}$ values are given for each sample, which act as light sources (luminescent samples). Standards from Phosphor Technology used, calibrated at $312 \mathrm{~nm}$ : red phosphor $\mathrm{Gd}_{2} \mathrm{O}_{2} \mathrm{~S}: \mathrm{Eu}(\mathrm{x}=0.667, \mathrm{y}=0.330)$ and green phosphor $\mathrm{Gd}_{2} \mathrm{O}_{2} \mathrm{~S}: \mathrm{Tb}(\mathrm{x}=0.328, \mathrm{y}=$ $0.537)$

\section{Coupled Thermal and IR analyses}

Coupled thermal (ATG/DSC) and IR analyses have been performed using a Perkin Elmer STA6000 thermal analyzer coupled to a Perkin Elmer Frontier IR spectrophotometer analyzer. Coupling was insured by a Perkin Elmer TL8000 transfer line. This allows simultaneous recording of the weight of the sample, the heat flux and the IR spectrum of the exhausted gases versus temperature. Measurements were performed in ceramic crucibles under a nitrogen atmosphere between room temperature and $900^{\circ} \mathrm{C}$ with a $20^{\circ} \mathrm{C} \cdot \mathrm{min}^{-1}$ heating rate. At the end of the experiment, the compound was maintained for one hour at $900^{\circ} \mathrm{C}$ under air atmosphere in order to complete the combustion. 


\section{RESULTS AND DISCUSSION.}

\section{$\left[\mathrm{Ce}(\mathrm{mip})_{3 / 2}\left(\mathrm{H}_{2} \mathrm{O}\right)_{5} \cdot 2 \mathrm{H}_{2} \mathrm{O}\right]_{\infty}$}

This compound has been obtained as single crystals only. Its crystal structure can be described as the superimposition of $1 \mathrm{D}$ molecular chains in which $\mathrm{Ce}^{3+}$ ions and (mip) $)^{2-}$ ligands alternate (Figure 4). There is only one independent $\mathrm{Ce}^{3+}$ ion in the crystal structure that is nine coordinated by five oxygen atoms from coordination water molecules and four oxygen atoms from two carboxylate clips that form a slightly distorted muffin (Table S2). A fully deprotonated ligand with a half occupancy factor is located between the chains and ensures the electro-neutrality of the crystal packing. Stability of the crystal packing is ensured by a complex hydrogen-bonds network that involves crystallization water molecules as well as $\pi$-stacking interactions. Indeed, phenyl groups of the free and coordinated ligands stack parallel to the $a$-axis. Free (mip) ${ }^{2-}$ ligands are disordered. The disorder model is drawn in scheme 2. Intra-molecular chain Ce-Ce shortest distances are $10.2 \AA$. Shortest distances between $\mathrm{Ce}^{3+}$ ions that belong to neighboring chains are $10.8 \AA$ along the $a$-axis and $6.0 \AA$ and $6.9 \AA$ in the $(b c)$ plane.

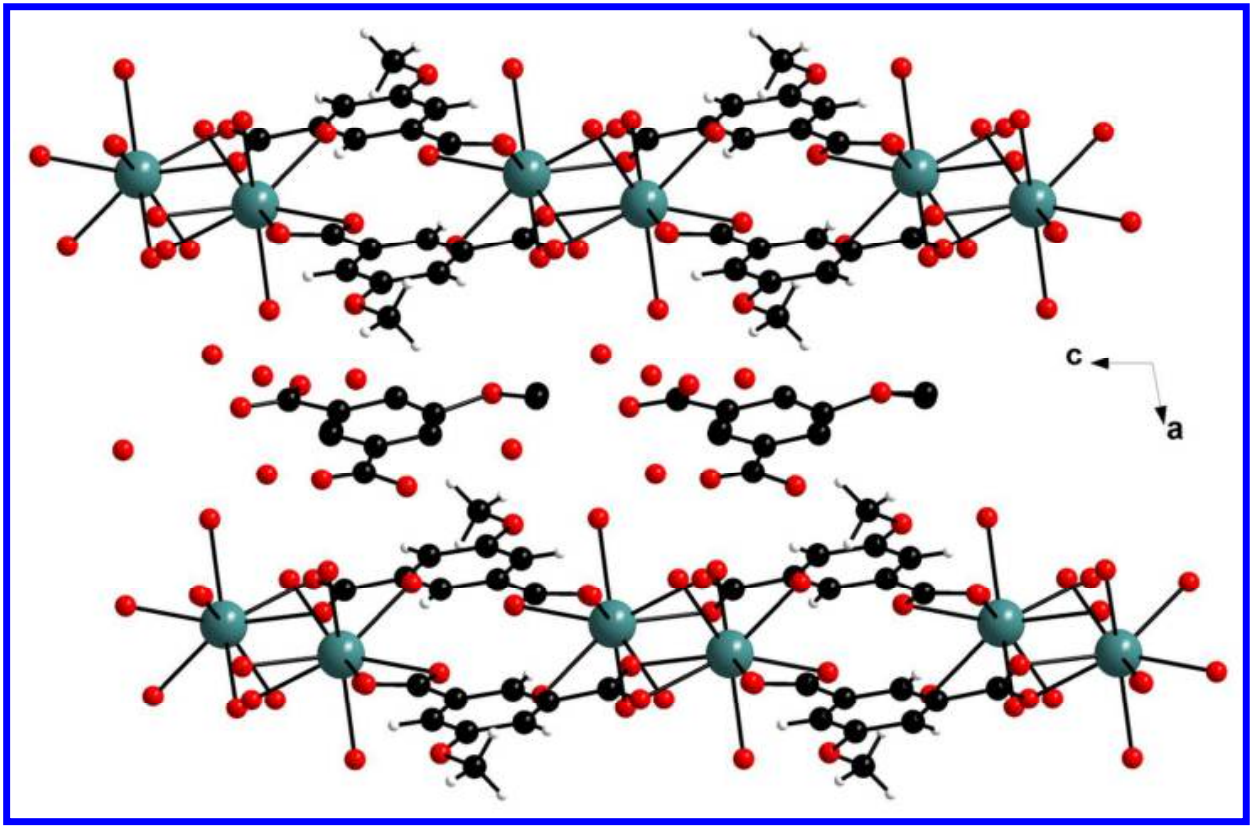


Figure 4. Projection view along the $b$-axis of $\left[\mathrm{Ce}(\mathrm{min})_{2}\left(\mathrm{H}_{2} \mathrm{O}\right)_{5} \cdot 2 \mathrm{H}_{2} \mathrm{O}\right]_{0}$.

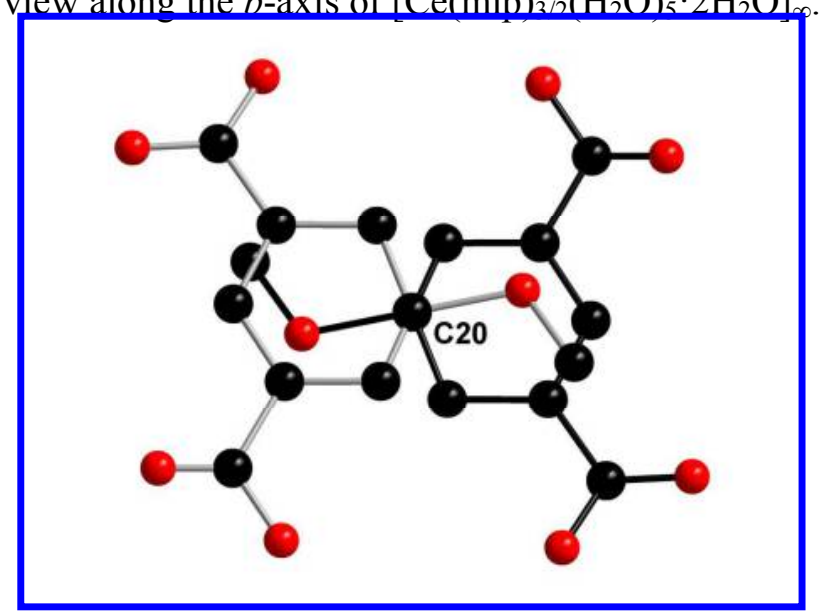

Scheme 2. Schematic representation of the uncoordinated (mip) ${ }^{2-}$ ligand. The two equiprobable configurations of the free ligand, the one with light grey bonds and the one with black bonds, share the $\mathrm{C} 20$ atom.

\section{$\left[\mathrm{Ln}(\operatorname{mip})(\mathrm{Hmip})\left(\mathrm{H}_{2} \mathrm{O}\right)_{5} \cdot \mathrm{H}_{2} \mathrm{O}\right]_{\infty}$ with $\mathrm{Ln}=\mathrm{La}, \mathrm{Ce}, \mathrm{Pr}$ or Gd}

Compounds that belong to the second series have general chemical formula $\left[\mathrm{Ln}(\mathrm{mip})(\mathrm{Hmip})\left(\mathrm{H}_{2} \mathrm{O}\right)_{5} \cdot \mathrm{H}_{2} \mathrm{O}\right]_{\infty}$ where Ln symbolizes a lanthanide ion. These compounds have been obtained in gels as single crystals for $\mathrm{Ln}=\mathrm{La}, \mathrm{Pr}, \mathrm{Gd}$ but they have only been obtained as microcrystalline powders for $\mathrm{Ln}=\mathrm{La}$ or Ce. Crystal structure has been solved on the Gd-containing compound and isostructurality of the La-, Ce- and Pr-derivatives has been assumed on the basis of X-ray diffraction measurements (Figure S4). This crystal structure can be described as the juxtaposition of 1D ribbon-like molecular motifs that spread parallel to the $b$-axis (Figure 5). There is only one crystallographically independent $\mathrm{Gd}^{3+}$ ion that is nine coordinated by four oxygen atoms from carboxylate functions and five oxygen atoms from coordination water molecules that form a slightly distorted capped square antiprism $(\text { Table S3) })^{[52]}$. Coordination modes of the (mip) $)^{2-}$ ligand that links the $\mathrm{Gd}^{3+}$ ions are drawn in Figure 5. 

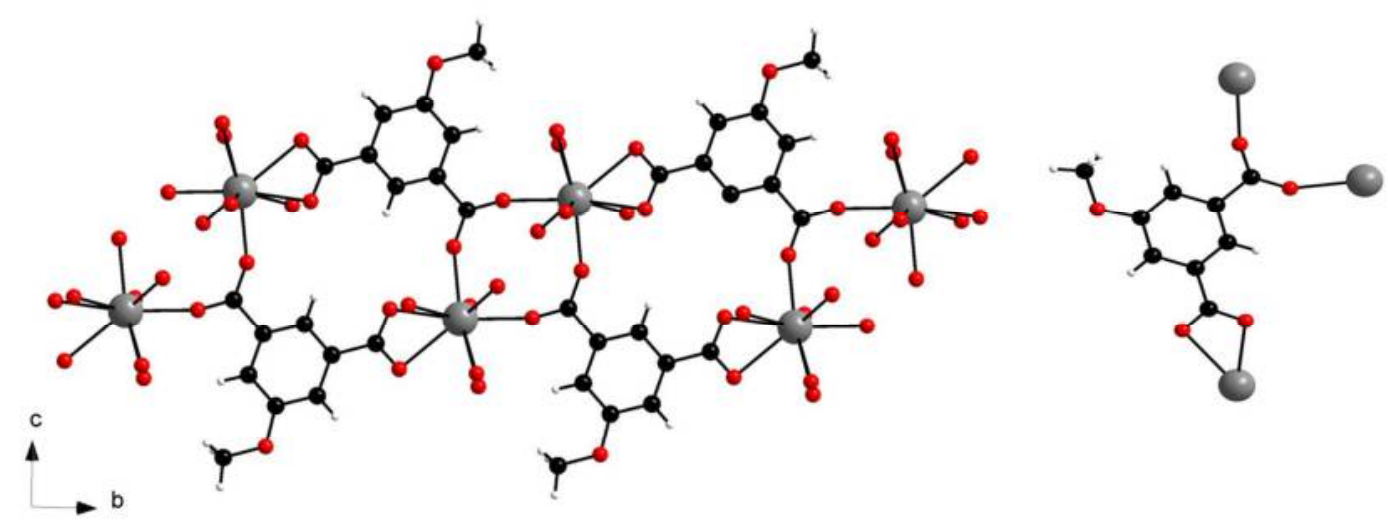

Figure 5. Left: Projection view along the $a$-axis of a ribbon-like molecular motif of $\left[\mathrm{Gd}(\mathrm{mip})(\mathrm{Hmip})\left(\mathrm{H}_{2} \mathrm{O}\right)_{5} \cdot \mathrm{H}_{2} \mathrm{O}\right]_{\infty}$. Right: coordination modes of the ligand (mip) ${ }^{2-}$.

In addition, there is one crystallization water molecule and one half-protonated ligand that lay between the ribbon-like molecular motifs (Scheme 3). Presence of an uncoordinated ligand between molecular motifs, that insures electro-neutrality of the crystal structure, has already been observed in lanthanide-based coordination polymers obtained with 5-hydroxybenzene-1,3-di-carboxylate. ${ }^{[30]}$ A complex network of hydrogen bonds and $\pi$-stacking interactions insure the stability of the crystal structure.

Coupled thermal (ATG/DSC) and IR analyses have been performed (Figure S6). They show the departure of the six water molecules per lanthanide ion at about $100^{\circ} \mathrm{C}$ (Exp. $20 \%$ Calc. $17.3 \%)$ 
Scheme 3. Perspective view of the half-protonated ligand (ball-and-stick model) between two ribbon-like molecular motifs in $\left[\mathrm{Gd}(\mathrm{mip})\left(\mathrm{H}(\mathrm{mip})\left(\mathrm{H}_{2} \mathrm{O}\right)_{5} \cdot \mathrm{H}_{2} \mathrm{O}\right]_{\infty}\right.$. Blue balls symbolize crystallization water molecules. Lanthanide ions coordination polyhedrons have been drawn and hydrogen atoms have been omitted for clarity.

It can be noticed that this crystal structure differs from the crystal structures of the lanthanide-based coordination polymers obtained with isophthalate, 5-amino-isophthalate or 5-hydroxy-isophthalate. ${ }^{[28,30-32]}$

\section{$\left[\mathrm{Ln}_{2}(\operatorname{mip})_{3}\left(\mathrm{H}_{2} \mathrm{O}\right)_{8} \cdot \mathbf{4 H _ { 2 }} \mathrm{O}\right]_{\infty}$ with $\mathrm{Ln}=\mathrm{Sm}-\mathrm{Yb}$ plus $\mathrm{Y}$.}

Compounds that have been obtained with lanthanide ions comprised between samarium and ytterbium plus yttrium constitute a family of isostructural compounds. Isostructurality of the compounds has been assumed on the basis of their powder X-ray diffraction patterns (Figure S5). The crystal structure has been solved on the basis of an Ycontaining single crystal. Once again this mono-dimensional crystal structure, is completely different from those that had been obtained with isophthalate, 5-amino-isophthalate or 5hydroxy-isophthalate. ${ }^{[28,30-32]}$ There are two independent $\mathrm{Y}^{3+}$ ions in this crystal structure. Y1 and Y2 are both nine-coordinated by five oxygen atoms from three carboxylate functions and 
four coordination water molecules that form slightly distorted capped square antiprisms ${ }^{[52]}$ (Figure 6 and Table S4). Two out of the three independent ligands bind Y1 and Y2 in a bisbidentate manner while the third one binds them in a bis-monodentate way (Figure 7).

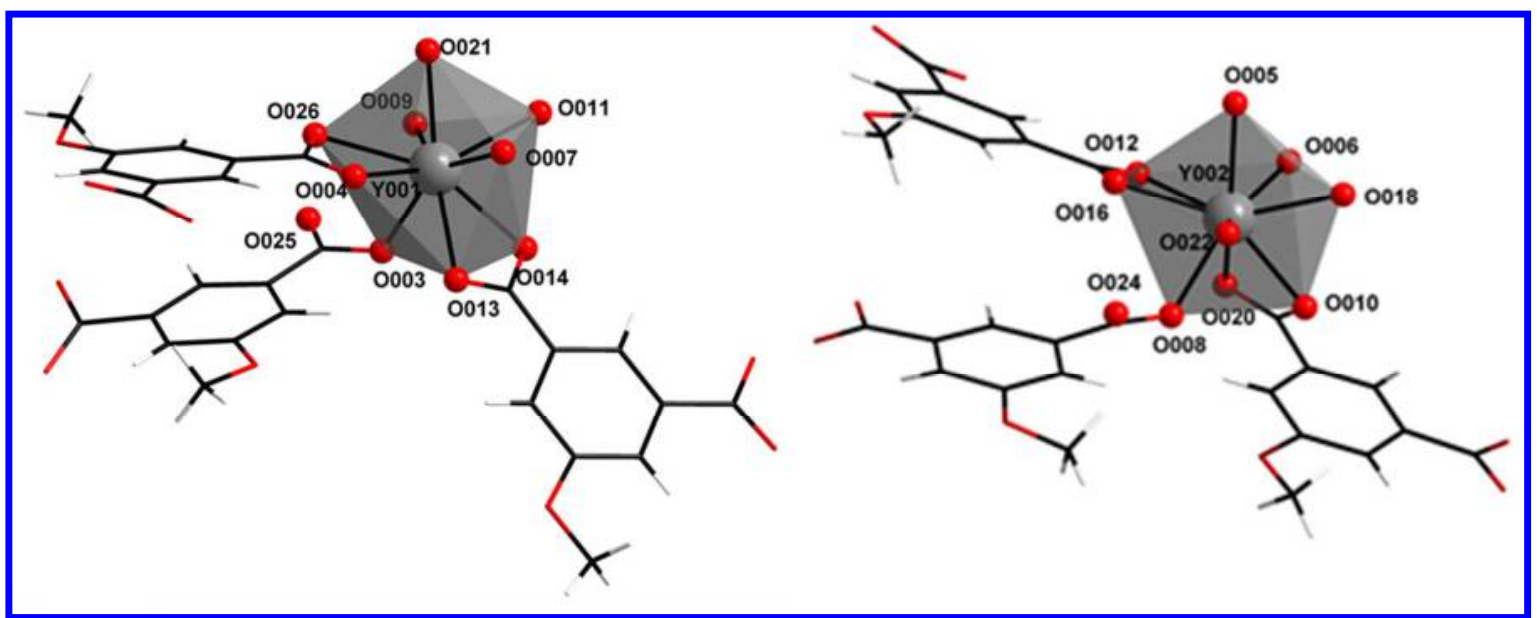

Figure 6. Extended coordination polyhedrons of Y1 (left) and Y2 (right) in $\left[\mathrm{Y}_{2}(\min )_{2}\left(\mathrm{H}_{2} \mathrm{O}\right)_{8} \cdot 4 \mathrm{H}_{2} \mathrm{O}\right]_{0}$

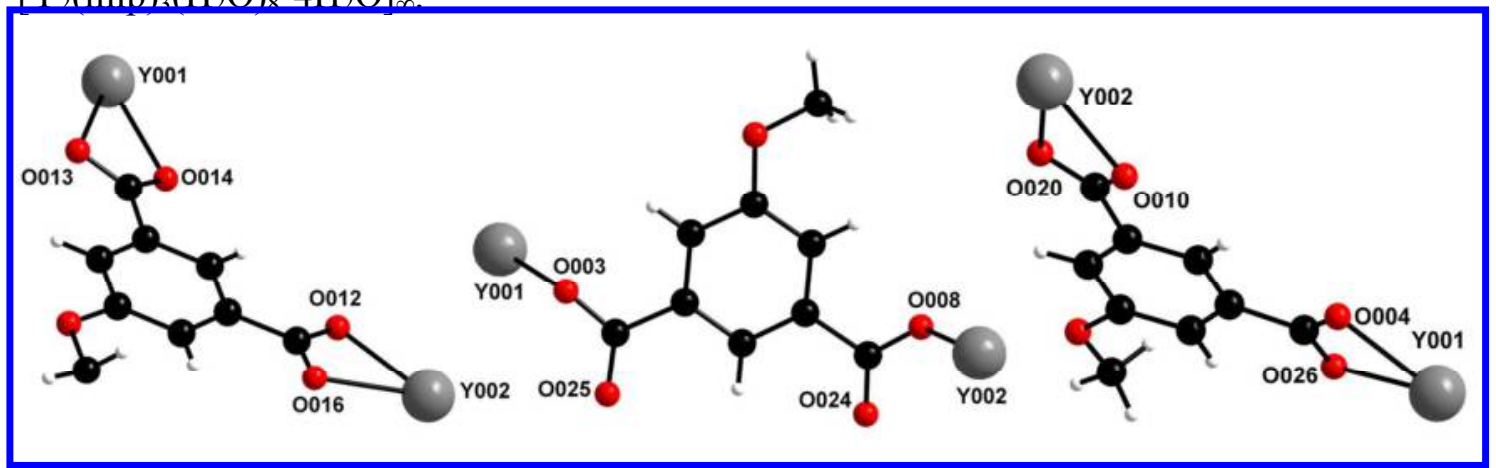

Figure 7. Coordination modes of the three independent ligands in $\left[\mathrm{Y}_{2}(\operatorname{mip})_{3}\left(\mathrm{H}_{2} \mathrm{O}\right)_{8} \cdot 4 \mathrm{H}_{2} \mathrm{O}\right]_{\infty}$.

The crystal structure can be described as the juxtaposition of wrapped ladder-like molecular motifs that spread parallel to the $a$-axis. Uprights are constituted by an alternation of $\mathrm{Y}^{3+}$ ions linked together by bis-bidentate ligands. Bis-monodentate ligands constitute the rungs of the ladder (Figure 8). Intermetallic distances between adjacent lanthanide ions that belong to the same molecular motif are close to $10 \AA$. These quite long intermetallic distances are rather rare in lanthanide-based coordination polymers made of poly-carboxylates as ligands because carboxylate functions adopt commonly a bridging bis-monodentate 
coordination mode that leads to short Ln-Ln distances $(\sim 4.5 \AA) .{ }^{[24]}$ However, ladder-like molecular motifs stack in such a way that the shortest intermetallic contacts between lanthanide ions that belong to neighboring motifs are only $6 \AA$ (See scheme 4).

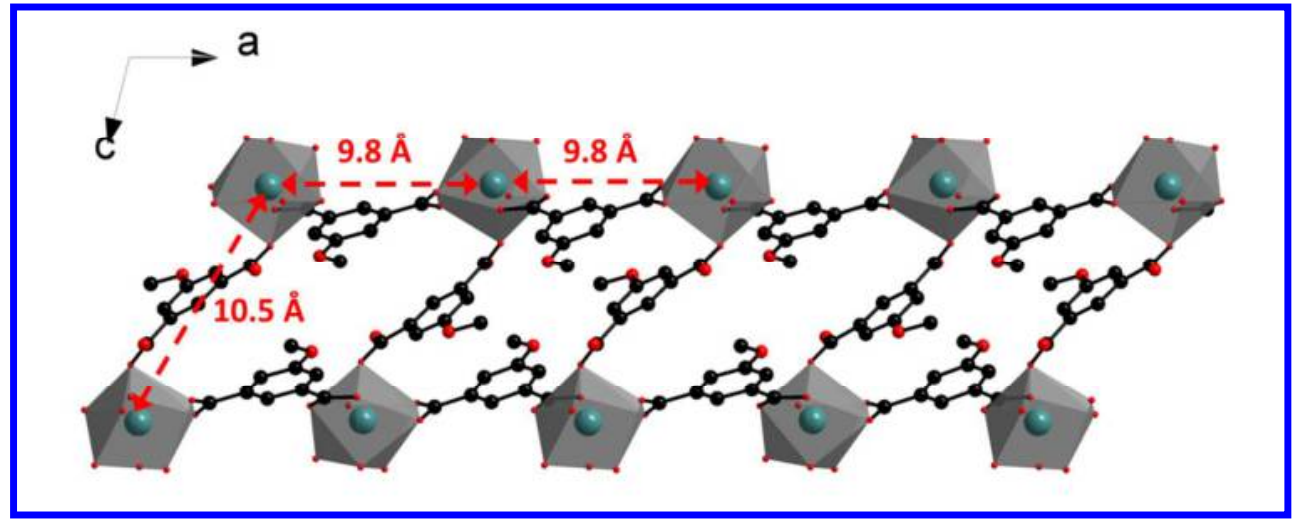

Figure 8. Ladder-like molecular motif in $\left[\mathrm{Y}_{2}(\operatorname{mip})_{3}\left(\mathrm{H}_{2} \mathrm{O}\right)_{8} \cdot 4 \mathrm{H}_{2} \mathrm{O}\right]_{\infty}$. Hydrogen atoms have been omitted for clarity.

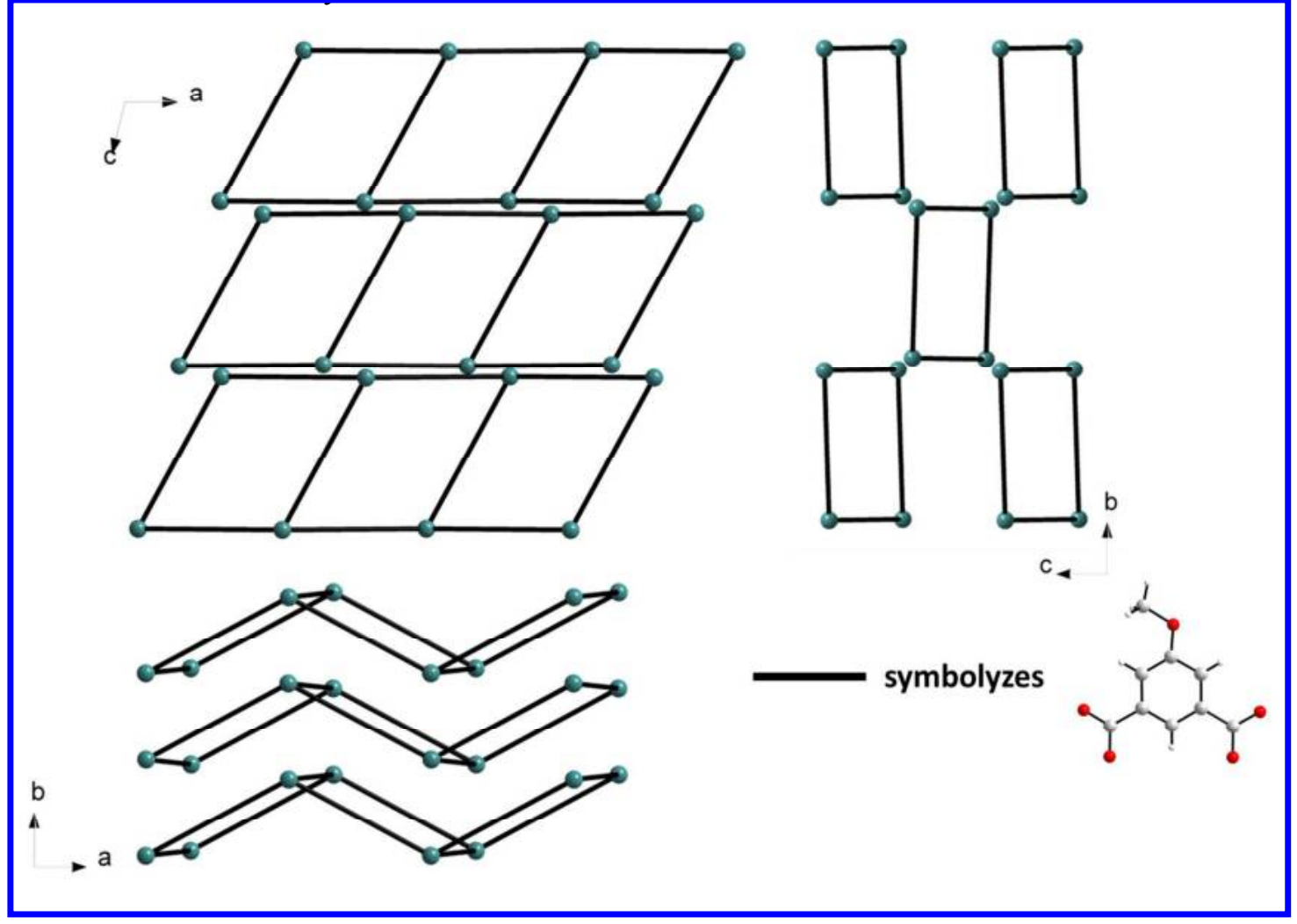

Scheme 4. Schematic projections views of the crystal packing of $\left[\mathrm{Y}_{2}(\mathrm{mip})_{3}\left(\mathrm{H}_{2} \mathrm{O}\right)_{8} \cdot 4 \mathrm{H}_{2} \mathrm{O}\right]_{\infty}$. 
With the rough model that has been described previously, ${ }^{[53]}$ the mean volume occupied by an $\mathrm{Y}^{3+}$ ion in this crystal structure is $\overline{\mathrm{v}}=464 \AA^{3}$, that is, the mean distance between two lanthanide ions is about $9.6 \AA\left(r=\sqrt[3]{\frac{3 \bar{v}}{4 \pi}}\right)$. This is quite interesting as far as luminescence properties are targeted. Indeed, it is well known ${ }^{[54]}$ that intermetallic energy transfers are less efficient when the lanthanide ions are more than $10 \AA$ far from each other. Therefore, in this crystal structure these energy transfers are expected to be weak.

Stability of the crystal packing is ensured by a strong hydrogen-bonds network that involves coordination and crystallization water molecules as well as oxygen atoms that belong to the ligands (See Table S5).

Coupled thermal analyses that have been performed on the basis of the Y-containing compound indicate a first weight loss centered at $125^{\circ} \mathrm{C}$ that corresponds to the departure of the twelve water molecules per formula unit (Exp.: 21.9\% - Calc.: 22.6\%). The dehydrated phase that is obtained remains stable up to about $500^{\circ} \mathrm{C}$. At last the ligand decomposes and $\mathrm{Y}_{2} \mathrm{O}_{3}$ is obtained (See Figure $\mathrm{S} 7$ ). Thermo-dependent powder X-ray diffraction shows that the dehydrated phase observed between $100^{\circ} \mathrm{C}$ and $500^{\circ} \mathrm{C}$ is different from the initial hydrated one (Figure S8). Moreover, even when exposed to wet atmosphere, this phase does not rehydrate (Figure S9). The irreversibility of the structural change and the robustness of the dehydrated phase could be related to the departure of four coordination water molecules per lanthanide ion and the presence of a non-coordinated oxygen atom from a carboxylate function in the vicinity of the under-crowded lanthanide ion that is available for coordination.

This series of compounds is of particular interest as far as strongly luminescent compounds are targeted. Indeed, the quite long mean intermetallic distance is supposed to favor luminescence because negligible intermetallic energy transfer is expected. Colorimetric coordinates and luminance of $\left[\mathrm{Ln}_{2}(\operatorname{mip})_{3}\left(\mathrm{H}_{2} \mathrm{O}\right)_{8} \cdot 4 \mathrm{H}_{2} \mathrm{O}\right]_{\infty}$ with $\mathrm{Ln}=$ Sm-Dy are reported in figure 9 and table S6. 

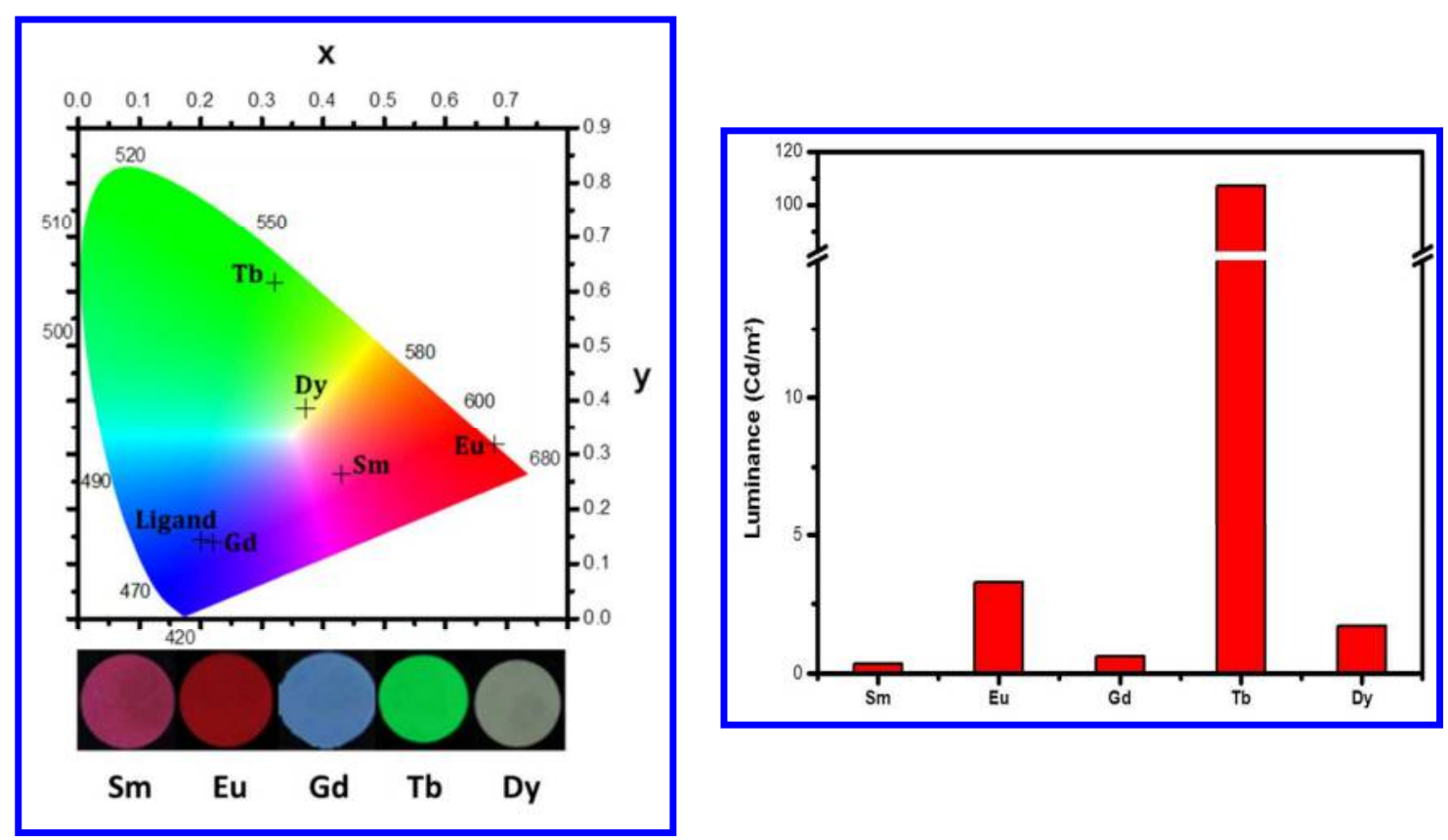

Figure 9. Left: Colorimetric coordinates and pictures under UV irradiation of $\left[\mathrm{Ln}_{2}(\mathrm{mip})_{3}\left(\mathrm{H}_{2} \mathrm{O}\right)_{8} \cdot 4 \mathrm{H}_{2} \mathrm{O}\right]_{\infty}$ with $\mathrm{Ln}=\operatorname{Sm}$-Dy $\left(\lambda_{\text {exc }}=312 \mathrm{~nm}\right)$. Right: Luminance of $\left[\mathrm{Ln}_{2}(\mathrm{mip})_{3}\left(\mathrm{H}_{2} \mathrm{O}\right)_{8} \cdot 4 \mathrm{H}_{2} \mathrm{O}\right]_{\infty}$ with $\mathrm{Ln}=$ Sm-Dy under UV excitation $\left(\lambda_{\text {exc }}=312 \mathrm{~nm}\right)$.

These measurements indicate that the luminance of the Tb-containing compound is significant $\left(107 \mathrm{~cd} . \mathrm{m}^{-2}\right)$. Actually, to the best of our knowledge, among all the lanthanidecontaining coordination polymers with benzene-poly-carboxylate derivatives as ligands whose luminance has been measured to date, only $\left[\mathrm{Tb}_{2}(\mathrm{bdc})_{3} \cdot 4 \mathrm{H}_{2} \mathrm{O}\right]_{\infty}$ (where bdc ${ }^{2-}$ stands for terephthalate) exhibits a higher luminance (142 cd. $\mathrm{m}^{-2}$ under similar operating conditions) ${ }^{[49]}$ Excitation and emission spectra of the compounds that involve $\mathrm{Sm}^{3+}, \mathrm{Eu}^{3+}, \mathrm{Tb}^{3+}$ or $\mathrm{Dy}^{3+}$ have been recorded (See Figure 10) and their calculated luminescence lifetimes and overall quantum yields are given in Table 4. 


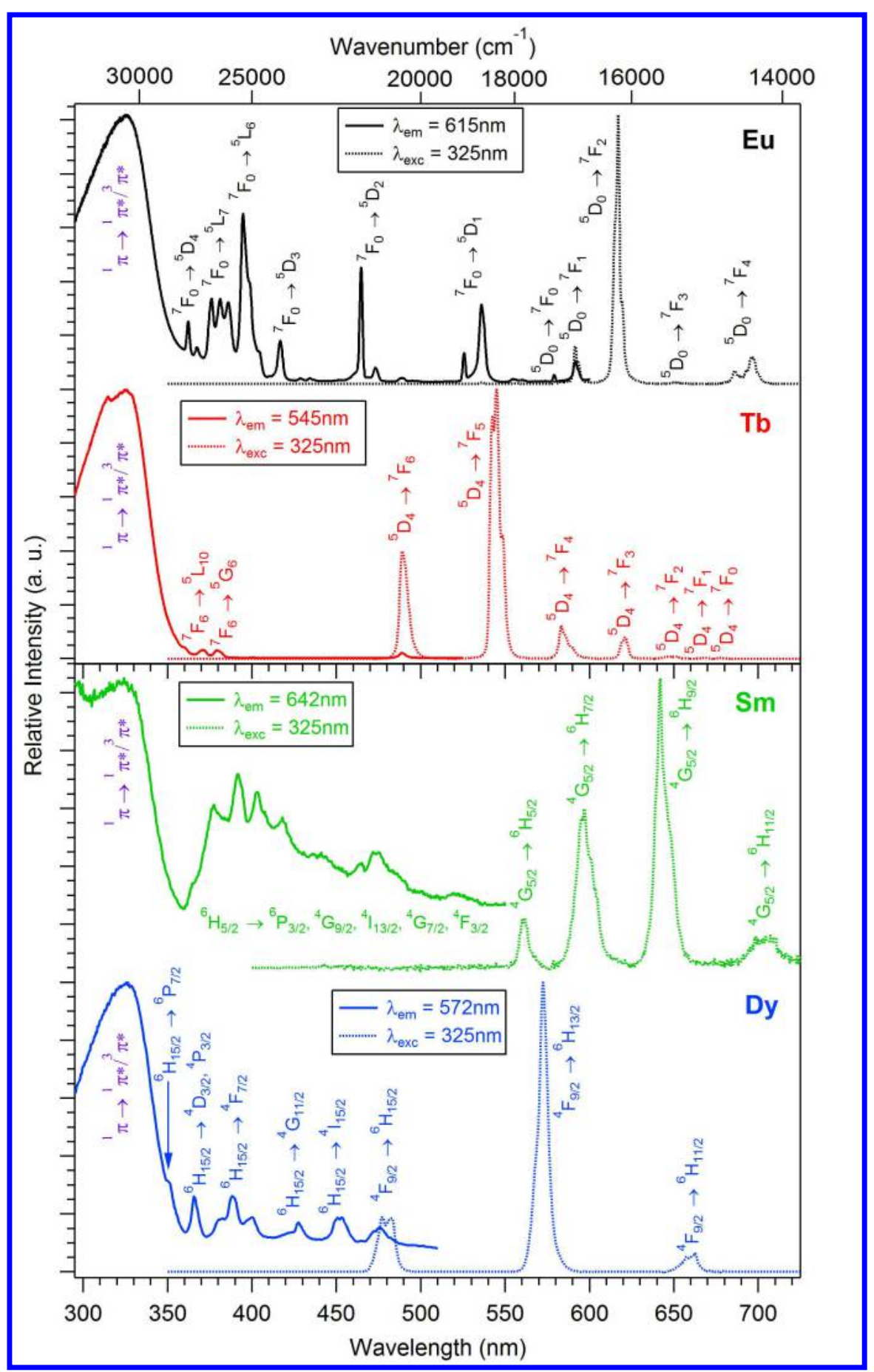

Figure 10. Excitation and emission spectra of $\left[\mathrm{Ln}_{2}(\mathrm{mip})_{3}\left(\mathrm{H}_{2} \mathrm{O}\right)_{8} \cdot 4 \mathrm{H}_{2} \mathrm{O}\right]_{\infty}$ with $\mathrm{Ln}=\mathrm{Eu}$ (black curves), Tb (red curves), Sm (green curves) and Dy (blue curves). $\lambda_{\text {exc }}=325 \mathrm{~nm}$. 
Table 4. Overall quantum yields and luminescence lifetimes of $\left[\mathrm{Ln}_{2}(\operatorname{mip})_{3}\left(\mathrm{H}_{2} \mathrm{O}\right)_{8} \cdot 4 \mathrm{H}_{2} \mathrm{O}\right]_{\infty}$ with $\mathrm{Ln}=\mathrm{Sm}, \mathrm{Eu}, \mathrm{Tb}$ or Dy $\left(\lambda_{\text {exc }}=\right.$ $325 \mathrm{~nm})$.

\begin{tabular}{lcc}
\hline & $Q_{\text {Ln }}^{\text {Ligand }}(\%)$ & $\tau_{\text {obs }}$ \\
\hline$\left[\mathrm{Sm}_{2}(\operatorname{mip})_{3}\left(\mathrm{H}_{2} \mathrm{O}\right)_{8} \cdot 4 \mathrm{H}_{2} \mathrm{O}\right]_{\infty}$ & $0.18(5)$ & $<10 \mu \mathrm{s}$ \\
{$\left[\mathrm{Eu}_{2}(\operatorname{mip})_{3}\left(\mathrm{H}_{2} \mathrm{O}\right)_{8} \cdot 4 \mathrm{H}_{2} \mathrm{O}\right]_{\infty}$} & $2.8(2)$ & $0.21(1) \mathrm{ms}$ \\
{$\left[\mathrm{Tb}_{2}(\operatorname{mip})_{3}\left(\mathrm{H}_{2} \mathrm{O}\right)_{8} \cdot 4 \mathrm{H}_{2} \mathrm{O}\right]_{\infty}$} & $41(3)$ & $0.71(1) \mathrm{ms}$ \\
{$\left[\mathrm{Dy}_{2}(\operatorname{mip})_{3}\left(\mathrm{H}_{2} \mathrm{O}\right)_{8} \cdot 4 \mathrm{H}_{2} \mathrm{O}\right]_{\infty}$} & $0.68(8)$ & $<10 \mu \mathrm{s}$ \\
\hline
\end{tabular}

These measurements indicate that the antenna effect is effective for all compounds. Indeed the four compounds can be excited at the same wavelength that corresponds to ligand absorption. This was expected because the energy of the first excited singlet state of the ligand (29000 $\mathrm{cm}^{-1}$ estimated on the basis of the excitation spectrum (Figure S10) of $\left.\left[\mathrm{Gd}_{2}(\mathrm{mip})_{3}\left(\mathrm{H}_{2} \mathrm{O}\right)_{8} \cdot 4 \mathrm{H}_{2} \mathrm{O}\right]_{\infty}\right)$ and of its first excited triplet state $\left(24400 \mathrm{~cm}^{-1}\right.$ estimated on the basis of the emission spectrum (Figure $\mathrm{S} 10$ ) recorded at $77 \mathrm{~K}$ of $\left[\mathrm{Gd}_{2}(\operatorname{mip})_{3}\left(\mathrm{H}_{2} \mathrm{O}\right)_{8} \cdot 4 \mathrm{H}_{2} \mathrm{O}\right]_{\infty}{ }_{\infty}^{[55]}$ ) are supposed, according to Latva's ${ }^{[56]}$ and Reinhouldt's ${ }^{[57]}$ empirical rules, to favor efficient antenna effect $\left(\Delta \mathrm{E}\left({ }^{1} \pi \pi^{*}{ }^{3} \pi \pi^{*}\right)=4600 \mathrm{~cm}^{-1}<5000 \mathrm{~cm}^{-1}\right)$. Additionally, it can be noticed that the phosphorescent lifetime of the triplet state is much longer $\left(\tau_{\mathrm{obs}}=39(3) \mathrm{ms}\right)$ than the one measured for other coordination polymers $\left(\tau_{\mathrm{obs}}=7.0(1) \mathrm{ms}\right.$ for $\left.\left[\mathrm{Gd}_{2}(\mathrm{bdc})_{3} \cdot 4 \mathrm{H}_{2} \mathrm{O}\right]_{\infty}\right){ }^{[49]}$

From a global point of view, it can be noticed that the overall quantum yields of the Eu-based compounds is very low compared with the one of the Tb-based compound (a factor 15 approximately). Because $\mathrm{CH}_{3}-\mathrm{O}-$ is a $+\mathrm{M}$ and $-\mathrm{I}$ group, a photo-induced electron transfer (PET) may occur for the Eu-based compound as observed for 5-hydroxy-isophthalate and 5amino-isophtahlates derivatives ${ }^{[28,30,31]}$. On the other hand, intrinsic quantum yield is low $\left(\mathrm{Q}_{\mathrm{Eu}}^{\mathrm{Eu}}=9.0(2) \%\right.$ measured with $\lambda_{\mathrm{exc}}=464.5 \mathrm{~nm}$ that corresponds to the ${ }^{7} \mathrm{~F}_{0} \rightarrow{ }^{5} \mathrm{D}_{2}$ transition $)$ which induces a low overall quantum yield despite sizeable sensitization $\left(\eta_{\text {sens }}=30 \%{ }^{[54]}\right)$.

Unfortunately, it has not been possible to evaluate accurately the intrinsic quantum yield of the terbium derivative because the direct excitation transition $\left({ }^{7} \mathrm{~F}_{6} \rightarrow{ }^{5} \mathrm{G}_{6}\right)$ overlaps with the excitation band of the ligand. Furthermore, an excitation of the following ${ }^{7} \mathrm{~F}_{6} \rightarrow{ }^{5} \mathrm{D}_{4}$ 
transition at $489 \mathrm{~nm}$ does not allow accurate calculation of the intrinsic quantum yield of the $\mathrm{Tb}^{3+}$ ion because of a weak absorption. However, tentative measurements that have been performed seem to indicate that the sensitization of the $\mathrm{Tb}^{3+}$ ion by the ligand is very high and likely close to $100 \%$.

For Sm- and Dy-based compounds, the overall quantum yield are lower than $1 \%$ indicating a weak antenna effect compared to Tb-based compounds (a factor 230 and 60 approximately with Sm and Dy, respectively).This can be attributed to the small energy gap between the emitting levels and the receiving levels of these two lanthanide ions. ${ }^{[54]}$

In the last years we have undertaken the investigation of heteronuclear lanthanidebased coordination polymers of formula $\left[\operatorname{Ln}_{2-2 x} \operatorname{Ln}_{2 x}(\mathrm{~L})_{3}\left(\mathrm{H}_{2} \mathrm{O}\right)_{\mathrm{y}}\right]_{\infty}$ (with $\mathrm{L}=$ benzenepolycarboxylate ligand) in order to afford materials where both brightness and color can be modulated. ${ }^{[14,16,30,49]}$ Such modification of the emissive properties when compared with homonuclear-based compounds is possible if strong intermetallic energy transfers are observed. In fact, for a given emissive compound, dilution with optically inactive lanthanide ion $\left(\mathrm{Gd}^{3+}, \ldots\right)$ can enhance the brightness up to $20 \%{ }^{[49]}$ whereas dilution with optically active ones lead to color change. This last modification is however rather tricky to control as the obtained color depends of the relative position of the emissive energy levels as well as the intrinsic quantum yield of each lanthanides. As a result, one lanthanide can overwhelm the emission of the other as observed on $\left[\mathrm{Tb}_{2-2 \mathrm{x}} \mathrm{Eu}_{2 \mathrm{x}}(\mathrm{bdc})_{3}\left(\mathrm{H}_{2} \mathrm{O}\right)_{4}\right]_{\infty}$ where full red emission is visible for $\mathrm{x}$ as low as $0.2 .^{[49]}$

The high $\mathrm{Ln}^{3+}-\mathrm{Ln}^{3+}$ mean distance in family 2, makes it a nice platform to test color modulation procedure with more predictable emission, ideally "additive color synthesis" as performed with classic dyes.

We have investigated two series of hetero-lanthanide coordination polymers with respective chemical formula $\left[\mathrm{Tb}_{2-2 \mathrm{x}} \mathrm{Gd}_{2 \mathrm{x}}(\mathrm{mip})_{3}\left(\mathrm{H}_{2} \mathrm{O}\right)_{8} \cdot 4 \mathrm{H}_{2} \mathrm{O}\right]_{\infty} \quad$ and 
$\left[\mathrm{Tb}_{2-2 \mathrm{x}} \mathrm{Eu}_{2 \mathrm{x}}(\mathrm{mip})_{3}\left(\mathrm{H}_{2} \mathrm{O}\right)_{8} \cdot 4 \mathrm{H}_{2} \mathrm{O}\right]_{\infty}$ with $0 \leq \mathrm{x} \leq 1$. The first series aims to quantify the intermetallic energy transfers and the second one to investigate the color modulation ability. (Figure 11). All these compounds present the same crystal structure than the homo-lanthanide compounds (Figures S11 and S12). Accurate metallic composition of each compound has been measured by EDS measurements (Tables S7 and S8). Powder X-ray diffraction patterns show neither evidence of segregation of the lanthanide ions nor bi-phasic character of the microcrystalline powders. ${ }^{[49]}$
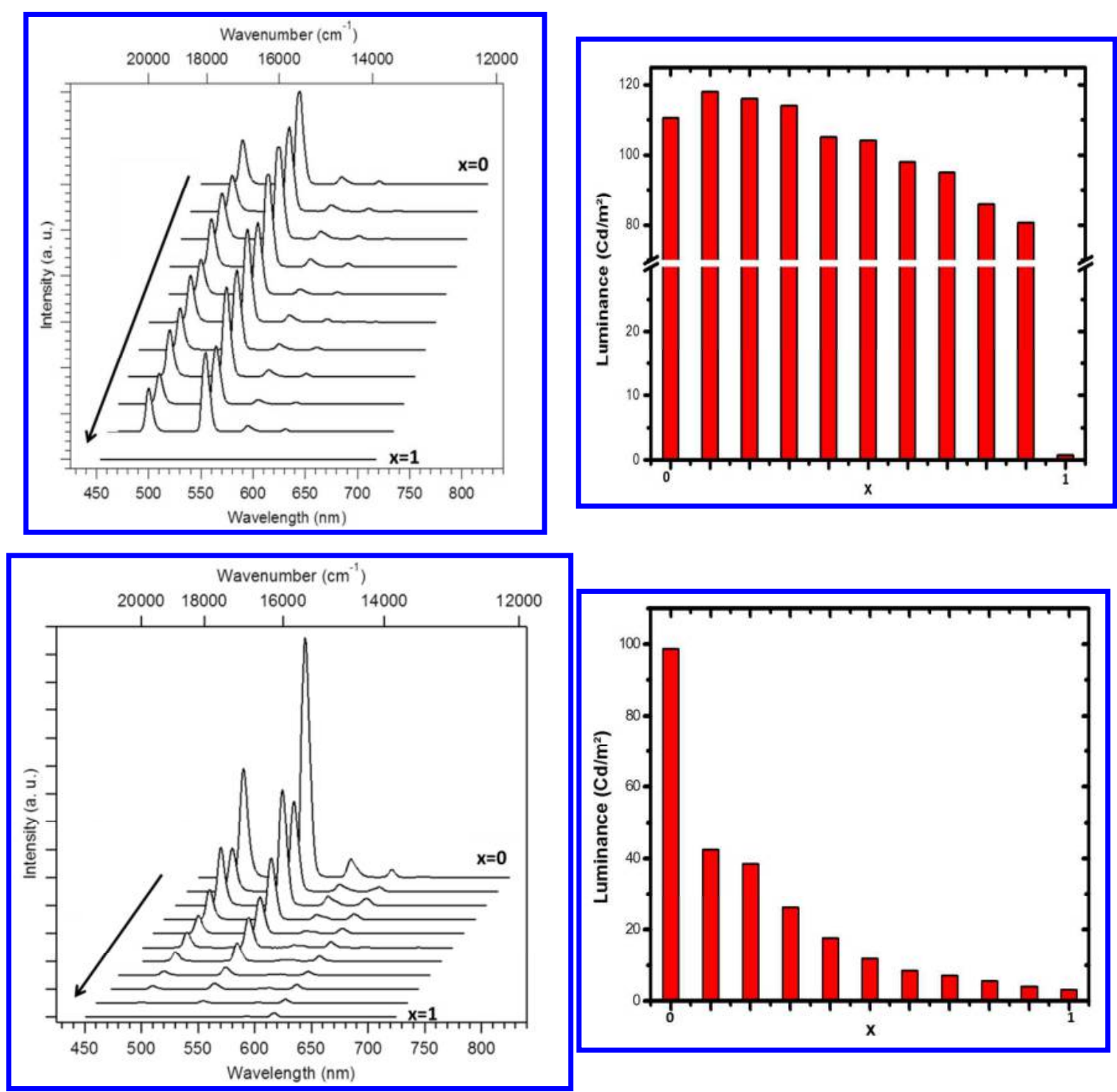

Figure 11. Emission spectra (left) and luminance measurements (right) under UV radiation $\left(\lambda_{\text {exc }}=325 \mathrm{~nm}\right)$ of $\left[\mathrm{Tb}_{2-2 \mathrm{x}} \mathrm{Gd}_{2 \mathrm{x}}(\mathrm{mip})_{3}\left(\mathrm{H}_{2} \mathrm{O}\right)_{8} \cdot 4 \mathrm{H}_{2} \mathrm{O}\right]_{\infty}$ with $0 \leq \mathrm{x} \leq 1$ (top) and $\left[\mathrm{Tb}_{2-2 \mathrm{x}} \mathrm{Eu}_{2 \mathrm{x}}(\mathrm{mip})_{3}\left(\mathrm{H}_{2} \mathrm{O}\right)_{8} \cdot 4 \mathrm{H}_{2} \mathrm{O}\right]_{\infty}$ with $0 \leq \mathrm{x} \leq 1$ (bottom). 
As anticipated, data that concern $\left[\mathrm{Tb}_{2-2 \mathrm{x}} \mathrm{Gd}_{2 \mathrm{x}}(\mathrm{mip})_{3}\left(\mathrm{H}_{2} \mathrm{O}\right)_{8} \cdot 4 \mathrm{H}_{2} \mathrm{O}\right]_{\infty}$ clearly show that there is little influence of the dilution of the $\mathrm{Tb}^{3+}$ ions by optically inactive $\mathrm{Gd}^{3+}$ ions. Indeed, luminance increases by only $7 \%$ for $\mathrm{x}=0.1$ which corresponds to a mean terbium-to-terbium distance of $10.7 \AA$. Then, it decreases progressively with the terbium content. This clearly evidences the weak $\mathrm{Tb}-\mathrm{Tb}$ intermetallic transfer within the series. In order to quantify this observation we have calculated the intermetallic energy transfer rate $\left(\eta_{\mathrm{ET}}=31(3) \%\right)$ using the relationship $\eta_{\mathrm{ET}}=1-\frac{\tau_{o b s}}{\tau_{0}}$ (where $\tau_{\mathrm{obs}}$ and $\tau_{0}$ are the luminescent lifetimes in presence or in absence of an acceptor respectively ${ }^{[54]}$ ) on the basis of the compounds $\left[\mathrm{TbEu}(\mathrm{mip})_{3}\left(\mathrm{H}_{2} \mathrm{O}\right)_{8} \cdot 4 \mathrm{H}_{2} \mathrm{O}\right]_{\infty}\left(\tau_{\mathrm{obs}}=0.45(3) \mathrm{ms}\right)$ and $\left[\mathrm{TbGd}(\operatorname{mip})_{3}\left(\mathrm{H}_{2} \mathrm{O}\right)_{8} \cdot 4 \mathrm{H}_{2} \mathrm{O}\right]_{\infty}\left(\tau_{0}=0.72(2)\right.$ ms). As a matter of comparison $\eta_{\mathrm{ET}}$ was $95 \%$ for $\left[\mathrm{TbEu}(\mathrm{bdc})_{3}\left(\mathrm{H}_{2} \mathrm{O}\right)_{4}\right]_{\infty}{ }^{[49]}$

The second series, $\left[\mathrm{Tb}_{2-2 \mathrm{x}} \mathrm{Eu}_{2 \mathrm{x}}(\mathrm{mip})_{3}\left(\mathrm{H}_{2} \mathrm{O}\right)_{8} \cdot 4 \mathrm{H}_{2} \mathrm{O}\right]_{\infty}$, show a significant color change upon $\mathrm{Eu}$ addition but with a trend that is significantly different from the $\left[\mathrm{Tb}_{2-2 \mathrm{x}} \mathrm{Eu}_{2 \mathrm{x}}(\mathrm{bdc})_{3}\left(\mathrm{H}_{2} \mathrm{O}\right)_{4}\right]_{\infty}$ series (figure 12). ${ }^{[24,49]}$ As foreseen above, a regular variation from green to red is observed on the powders. This can be related to the weak Tb-to-Eu energy transfer. It is worth notice that similar trend is visible on single crystals that have been obtained by slow evaporation of the filtrates retrieved after the microcrystalline powders preparation. This further strongly suggests the monophasic character of the microcrystalline powders and the random distribution of the lanthanide ions over the metallic sites of the crystal structure. 




Figure 12. Colorimetric coordinates (top) and pictures of pellets of microcrystalline powders and of single crystals (middle) under UV irradiation $\left(\lambda_{\text {exc }}=312 \mathrm{~nm}\right)$ of $\left[\mathrm{Tb}_{2-2 \mathrm{x}} \mathrm{Eu}_{2 \mathrm{x}}(\mathrm{mip})_{3}\left(\mathrm{H}_{2} \mathrm{O}\right)_{8} \cdot 4 \mathrm{H}_{2} \mathrm{O}\right]_{\infty}$ with $0 \leq \mathrm{x} \leq 1$. Bottom; comparison of the evolution of the colorimetric coordinates versus $x$ of $\left[\mathrm{Tb}_{2-2 x} \mathrm{Eu}_{2 x}(\mathrm{mip})_{3}\left(\mathrm{H}_{2} \mathrm{O}\right)_{8} \cdot 4 \mathrm{H}_{2} \mathrm{O}\right]_{\infty}$ (low intermetallic energy transfer) in black and of $\left[\mathrm{Tb}_{2-2 \mathrm{x}} \mathrm{Eu}_{2 \mathrm{x}}(\mathrm{bdc})_{3}\left(\mathrm{H}_{2} \mathrm{O}\right)_{4}\right]_{\infty}$ (strong intermetallic transfer) in 
light grey. $\mathrm{x}$ and $\mathrm{y}$ colorimetric coordinates are symbolized by circles and squares respectively. Curves that correspond to $\left[\mathrm{Tb}_{2-2 \mathrm{x}} \mathrm{Eu}_{2 \mathrm{x}}(\mathrm{bdc})_{3}\left(\mathrm{H}_{2} \mathrm{O}\right)_{4}\right]_{\infty}$ series are redrawn from reference $\left[{ }^{49}\right]$.

\section{CONCLUSION AND OUTLOOKS}

In this paper, we described the first three series of lanthanide-based coordination polymers with 5-methoxy-isophthalate as ligand. One of the families is particularly interesting as far as potential applications are targeted. Indeed, the bright luminescence exhibited by some of the compounds that constitute this series associated with the weak intermetallic transfer allow new lanthanide ions combinations with new luminescent properties. In particular, the color modulation within a heteronuclear family is particularly efficient and predictable and can be based on a simple colors addition technique. This strategy could lead to molecular bar codes exhibiting luminescent properties in different spectral domains. We are convinced that this opens new opportunities in the field of anti-counterfeiting taggants. Our group is currently working along this line.

\section{ACKOWLEDGEMENTS}

The French Cooperation Agency in Senegal is acknowledged for financial support. The CDIFX of Rennes is acknowledged for single crystal X-ray diffraction data collection.

\section{SUPPORTING INFORMATION}

Experimental and simulated powder X-ray diffraction patterns of $\mathrm{Na}_{2}(\mathrm{mip}) \cdot 7 \mathrm{H}_{2} \mathrm{O}$ (Figure $\mathrm{S} 1$ ). ATG/DSC of $\mathrm{Na}_{2}$ (mip) $\cdot 7 \mathrm{H}_{2} \mathrm{O}$ between room temperature and $300^{\circ} \mathrm{C}$ under $\mathrm{N}_{2}$ flux. IR spectra of the exhausted gas during thermal analyses versus temperature. IR spectrum recorded at $\mathrm{T}=90^{\circ} \mathrm{C}$ (Figure S2). Liquid state UV-visible absorption spectrum of a diluted aqueous solution of $\mathrm{Na}_{2}$ (mip) $7 \mathrm{H}_{2} \mathrm{O}$ (Figure $\mathrm{S} 3$ ). Chemical analyzes for compounds that constitute families (1) and (2) (Table S1). Experimental and simulated powder X-ray diffraction patterns 
of compounds with general chemical formula $\left[\mathrm{Ln}(\mathrm{mip})(\mathrm{Hmip})\left(\mathrm{H}_{2} \mathrm{O}\right)_{5} \cdot \mathrm{H}_{2} \mathrm{O}\right]_{\infty}$ with $\mathrm{Ln}=\mathrm{La}$ or Ce (Figure S4). Experimental and simulated powder X-ray diffraction patterns of compounds that have general chemical formula $\left[\mathrm{Ln}_{2}(\operatorname{mip})_{3}\left(\mathrm{H}_{2} \mathrm{O}\right)_{8} \cdot 4 \mathrm{H}_{2} \mathrm{O}\right]_{\infty}$ with $\mathrm{Ln}=$ Sm-Er plus Y (Figure S5). Continuous Shape Measurements (CSM) performed on the Ce center of $\left[\mathrm{Ce}(\mathrm{mip})_{3 / 2}\left(\mathrm{H}_{2} \mathrm{O}\right)_{5} \cdot 2 \mathrm{H}_{2} \mathrm{O}\right]_{\infty}($ Table S2). Continuous Shape Measurements $(\mathrm{CSM})$ performed on the $\mathrm{Gd}$ center of $\left[\mathrm{Gd}(\mathrm{mip})(\mathrm{Hmip})\left(\mathrm{H}_{2} \mathrm{O}\right)_{5} \cdot \mathrm{H}_{2} \mathrm{O}\right]_{\infty} \quad($ Table $\quad \mathrm{S} 3) . \quad$ ATG/DSC of $\left.\left[\mathrm{La}(\mathrm{mip})(\mathrm{Hmip})\left(\mathrm{H}_{2} \mathrm{O}\right)_{5}\right] \cdot \mathrm{H}_{2} \mathrm{O}\right]_{\infty}$. IR spectra versus temperature of the exhausted gas during thermal analysis. IR spectrum recorded at $90^{\circ} \mathrm{C}$ (Figure S6). Continuous Shape Measurements (CSM) performed on the $\mathrm{Y}$ centers of $\left[\operatorname{Ln}_{2}(\mathrm{mip})_{3}\left(\mathrm{H}_{2} \mathrm{O}\right)_{8} \cdot 4 \mathrm{H}_{2} \mathrm{O}\right]_{\infty}$ (Table S4). Selected hydrogen-bond distances in $\left[\mathrm{Y}_{2}(\mathrm{mip})_{3}\left(\mathrm{H}_{2} \mathrm{O}\right)_{8} \cdot 4 \mathrm{H}_{2} \mathrm{O}\right]_{\infty}$ (Table S5). ATG/DSC of $\left[\mathrm{Y}_{2}(\mathrm{mip})_{3}\left(\mathrm{H}_{2} \mathrm{O}\right)_{8} \cdot 4 \mathrm{H}_{2} \mathrm{O}\right]_{\infty}$. IR spectra versus temperature of the exhausted gas during thermal analysis. IR spectrum recorded at $90^{\circ} \mathrm{C}$ (Figure S7). Thermo-dependent powder X-ray diffraction patterns of $\left[\mathrm{Y}_{2}(\mathrm{mip})_{3}\left(\mathrm{H}_{2} \mathrm{O}\right)_{8} \cdot 4 \mathrm{H}_{2} \mathrm{O}\right]_{\infty}$ (Figure S8). Powder X-ray diffraction patterns of $\left[\mathrm{Y}_{2}(\mathrm{mip})_{3}\right]_{\infty}$ : (a) as obtained by dehydration at $200^{\circ} \mathrm{C}$; (b) after exposure to ambient air ; (c) after immersion in water (Figure S9). Numerical values for colorimetric coordinates and luminance of $\mathrm{Na}_{2}(\mathrm{mip}) \cdot 7 \mathrm{H}_{2} \mathrm{O}$ and $\left[\mathrm{Ln}_{2}(\mathrm{mip})_{3}\left(\mathrm{H}_{2} \mathrm{O}\right)_{8} \cdot 4 \mathrm{H}_{2} \mathrm{O}\right]_{\infty}$ with $\mathrm{Ln}=\mathrm{Sm}$ Dy under UV excitation $\left(\lambda_{\mathrm{exc}}=312 \mathrm{~nm}\right)$ (Table S6). Solid state UV-vis absorption spectrum of $\left[\mathrm{Gd}_{2}(\operatorname{mip})_{3}\left(\mathrm{H}_{2} \mathrm{O}\right)_{8} \cdot 4 \mathrm{H}_{2} \mathrm{O}\right]_{\infty}$. Solid state excitation and emission spectra recorded at $77 \mathrm{~K}$ of $\left[\mathrm{Gd}_{2}(\mathrm{mip})_{3}\left(\mathrm{H}_{2} \mathrm{O}\right)_{8} \cdot 4 \mathrm{H}_{2} \mathrm{O}\right]_{\infty}$ (Figure $\left.\mathrm{S} 10\right)$. Powder diffraction diagrams of $\left[\mathrm{Tb}_{2}\right.$ $\left.{ }_{2 \mathrm{x}} \mathrm{Gd}_{2 \mathrm{x}}(\operatorname{mip})_{3}\left(\mathrm{H}_{2} \mathrm{O}\right)_{8} \cdot 4 \mathrm{H}_{2} \mathrm{O}\right]_{\infty}$ with $0 \leq \mathrm{x} \leq 1$ (Figure $\mathrm{S} 11$ ). Powder diffraction diagrams of $\left[\mathrm{Tb}_{2-}\right.$ $\left.{ }_{2 x} \mathrm{Eu}_{2 \mathrm{x}}(\mathrm{mip})_{3}\left(\mathrm{H}_{2} \mathrm{O}\right)_{8} \cdot 4 \mathrm{H}_{2} \mathrm{O}\right]_{\infty}$ with $0 \leq \mathrm{x} \leq 1$ (Figure S12). Metallic contents measured by EDS for $\left[\mathrm{Tb}_{2-2 \mathrm{x}} \mathrm{Gd}_{2 \mathrm{x}}(\operatorname{mip})_{3}\left(\mathrm{H}_{2} \mathrm{O}\right)_{8} \cdot 4 \mathrm{H}_{2} \mathrm{O}\right]_{\infty}$ with $0<\mathrm{x}<1$ (Table S7). Metallic contents measured by EDS for $\left[\mathrm{Tb}_{2-2 \mathrm{x}} \mathrm{Eu}_{2 \mathrm{x}}(\mathrm{mip})_{3}\left(\mathrm{H}_{2} \mathrm{O}\right)_{8} \cdot 4 \mathrm{H}_{2} \mathrm{O}\right]_{\infty}$ with $0<\mathrm{x}<1$ (Table S8).

The Supporting Information is available free of charge on the ACS Publications website. 


\section{REFERENCES}

1. Guillerm, V.; Weselinski, L.; Belmabkhout, Y.; Cairns, A. J.; D'Elia, V.; Wojtas, L.; Adil, K.; Eddaoudi, M., Nature Chemistry 2014, 6, 673-680.

2. Eddaoudi, M.; Kim, J.; Rosi, N.; Vodak, D.; Wachter, J.; O'Keeffe, M.; Yaghi, O. M., Science 2002, 295, 469-472.

3. Yaghi, O. M.; Li, G.; Li, H., Nature 1995, 378, 703-706.

4. Yaghi, O. M.; Li, H. L., J. Am. Chem. Soc. 1995, 117, 10401-10402.

5. Surblé, S.; Serre, C.; Millange, F.; Férey, G., Solid State Sci. 2006, 8, 413-417.

6. Millange, F.; Serre, C.; Marrot, J.; Gardant, N.; Pelle, F.; Férey, G., J. Mater. Chem. 2004, 14, 642-645.

7. Serre, C.; Millange, F.; Thouvenot, C.; Gardant, N.; Pelle, F.; Ferey, G., J. Mater. Chem. 2004, 14, 1540-1543.

8. Kustaryono, D.; Kerbellec, N.; Calvez, G.; Daiguebonne, C.; Guillou, O., Cryst. Growth Des. 2010, 10, 775-781.

9. Kerbellec, N.; Daiguebonne, C.; Bernot, K.; Guillou, O.; Le Guillou, X., J. Alloys Compd. 2008, 451, 377-383.

10. Calvez, G.; Bernot, K.; Guillou, O.; Daiguebonne, C.; Caneschi, A.; Mahé, N., Inorg. Chim. Acta 2008, 361, 3997-4003.

11. Jeon, J. R.; Clérac, R., Dalton Trans. 2012, 41, 9569-9586.

12. Bernot, K.; Luzon, J.; Caneschi, A.; Gatteschi, D.; Sessoli, R.; Bogani, L.; Vindigni, A.; Rettori, A.; Pini, M. G., Phys. Rev. B 2009, 79, 134419 1-11.

13. Yi, X.; Calvez, G.; Daiguebonne, C.; Guillou, O.; Bernot, K., Inora. Chem. 2015, 54, 5213-5219.

14. Fan, X.; Freslon, S.; Daiguebonne, C.; Le Polles, L.; Calvez, G.; Bernot, K.; Guillou, O., Inorg. Chem. 2015, 54, 5534-5546.

15. Le Natur, F.; Calvez, G.; Daiguebonne, C.; Guillou, O.; Bernot, K.; Ledoux, J.; Le Polles, L.; Roiland, C., Inora. Chem. 2013, 52, 6720-6730.

16. Freslon, S.; Luo, Y.; Daiguebonne, C.; Calvez, G.; Bernot, K.; Guillou, O., Inorg. Chem. 2016, 55, 794-802.

17. Lan, A. J.; Li, K. H.; Wu, H. H.; Olson, D. H.; Emge, T. J.; Ki, W.; Hong, M. C.; Li, J., Angew. Chem. Int. Ed. 2009, 48, 2334-2338.

18. Feng, J.; Zhang, H. J., Chem. Soc. Rev. 2013, 42, 387-410.

19. Cui, Y.; Yue, Y.; Qian, G.; Chen, B., Chem. Rev. 2012, 1126-1162.

20. Cui, Y.; Xu, H.; Yue, Y.; Guo, Z.; Yu, J.; Chen, Z.; Gao, J.; Yang, Y.; Qian, G.; Chen, B., J. Am. Chem. Soc. 2012, 134, 3979-3982.

21. Serre, C.; Millange, F.; Thouvenot, C.; Gardant, N.; Pelle, F.; Ferey, G., J. Mater. Chem. 2004, $14,1540-1543$.

22. Reddy, M. L. P.; Sivakumar, S., Dalton Trans. 2013, 42, 2663-2678.

23. Guillou, O.; Daiguebonne, C.; Calvez, G.; Bernot, K., Accounts Chem. Res. 2016, 49, 844-856.

24. Kerbellec, N.; Kustaryono, D.; Haquin, V.; Etienne, M.; Daiguebonne, C.; Guillou, O., Inorg. Chem. 2009, 48, 2837-2843.

25. Yang, Q. Y.; Pan, M.; Wei, S. C.; Li, K.; Du, B. B.; Su, C. Y., Inora. Chem. 2015, 54, 5707-5716.

26. Daiguebonne, C.; Gérault, Y.; Guillou, O.; Lecerf, A.; Boubekeur, K.; Batail, P.; Kahn, M.; Kahn, O., L.Allovs Comod. 1998, 275-277, 50-53.

27. Guillou, O.; Daiguebonne, C., Lanthanide ions containing coordination polymers. In Handbook on the Physics and Chemistry of Rare Eaths (vol 34), Gschneider, K. A.; Bünzli, J. C. G.; Pecharsky, V. K., Eds. Elsevier: Amsterdam, 2005; Vol. 34, pp 359-404.

28. Freslon, S.; Luo, Y.; Calvez, G.; Daiguebonne, C.; Guillou, O.; Bernot, K.; Michel, V.; Fan, X., Inorg. Chem. 2014, 53, 1217-1228.

29. Fan, X.; Daiguebonne, C.; Guillou, O.; Camara, M., Acta Crvstallogr. E 2014, E70, m181-m182. 
30. Fan, X.; Freslon, S.; Daiguebonne, C.; Calvez, G.; Le Polles, L.; Bernot, K.; Guillou, O., J. Mater. Chem. C 2014, 5510-5525.

31. Luo, Y.; Calvez, G.; Freslon, S.; Bernot, K.; Daiguebonne, C.; Guillou, O., Eur. J. Inorg. Chem. 2011, 3705-3716.

32. Daiguebonne, C.; Kerbellec, N.; Gérault, Y.; Guillou, O., J. Allovs Compd. 2008, 451, 372-376.

33. Mc Cormick, L. J.; Morris, S. A.; Teat, S. J.; Mc Pherson, M. J.; Slawin, A. M. Z.; Morris, R. E., Dalton Trans. 2015, 44, 17686-17695.

34. Zhang, H. J., Z. Kristalloar. NCS 2011, 226, 629-630.

35. Tian, C.; Lin, Z.; Du, S., Cryst. Growth Des. 2013, 13, 3746-3753.

36. Desreux, J. F., In Lanthanide Probes in Life, Chemical and Earth Sciences, Choppin, G. R.; Bünzli, J. C. G., Eds. Elsevier: Amsterdam, 1989; Vol. Elsevier, p 43.

37. Henisch, H. K., Crystals in Gels and Liesegang Rings. Cambridge University Press: Cambridge, 1988.

38. Henisch, H. K.; Rustum, R., Crystal Growth in Gels. The Pennsylvania State University Press: 1970; p 1-196.

39. Daiguebonne, C.; Deluzet, A.; Camara, M.; Boubekeur, K.; Audebrand, N.; Gérault, Y.; Baux, C.; Guillou, O., Cryst. Growth Des. 2003, 3, 1015-1020.

40. Sheldrick, G. M., Acta Crystallogr. A 2008, 64, 112-122.

41. Inc., B. A. SAINT, V837A; Brucker: Madison, Wisconsin, USA, 2014.

42. Inc, B. A. SADABS, 2014/5; Bruker: Madison, Wisconsin, USA, 2014.

43. Inc, B. A. APEX3, Bruker: Madison, Wisconsin, USA, 2015.

44. Altomare, A.; Burla, M. C.; Camalli, M.; Carrozzini, B.; Cascarano, G.; Giacovazzo, C.; Guagliardi, A.; Moliterni, A. G. G.; Polidori, G.; Rizzi, A. C., J. Appl. Crustallogr. 1999, 32, 339-340.

45. Sheldrick, G. M.; Schneider, T. R., Macromol. Crvstalloar. B 1997, 319-343.

46. Farrugia, L. J., J. Appl. Crvstallogr. 2012, 45, 849-854.

47. Roisnel, T.; Rodriguez-Carjaval, J., J. Mater. Sci. Forum 2001, 378, 118-123.

48. Kraus, W.; Nolze, G., J. Appl. Crvstallogr. 1996, 29, 301-303.

49. Haquin, V.; Etienne, M.; Daiguebonne, C.; Freslon, S.; Calvez, G.; Bernot, K.; Le Polles, L.; Ashbrook, S. E.; Mitchell, M. R.; Bünzli, J. C. G.; Guillou, O., Eur. J. Inorg. Chem. 2013, 3464-3476.

50. Wyszecki, G., Colorimetry. In Handbook of Optics, Driscoll, W. G.; Vaughan, W., Eds. Mac Graw-Hill Book Company: New-York, 1978; pp 1-15.

51. CIE, International Commission on Illumination - Technical report. CIE: 1995; Vol. 13-3, p 16.

52. Casanova, D.; Llunell, M.; Alemany, P.; Alvarez, S., Chem. - Eur. J. 2005, 11, 1479-1494.

53. Luo, Y.; Zheng, Y.; Calvez, G.; Freslon, S.; Bernot, K.; Daiguebonne, C.; Roisnel, T.; Guillou, O., Crvst. Ena. Comm. 2013, 15, 706-720.

54. Bünzli, J. C. G.; Eliseeva, S. V., Basics of lanthanide photophysics. In Lanthanide Luminescence, Hänninen, P.; Härmä, H., Eds. Springer Berlin Heidelberg: 2010; pp 1-45.

55. Gutierrez, F.; Tedeschi, C.; Maron, L.; Daudey, J.-P.; Poteau, R.; Azema, J.; Tisnes, P.; Picard, C., Dalton Trans. 2004, 1334-1347.

56. Latva, M.; Takalo, H.; Mukkala, V.-M.; Matachescu, C.; Rodriguez-Ubis, J. C.; Kankare, J., J. Lumin. 1997, 75, 149-169.

57. Steemers, F. J.; Verboom, W.; Reinhoudt, D. N.; Van der Tol, E. B.; Verhoeven, J. W., J. Am. Chem. Soc. 1995, 117, 9408-9414. 


\section{FOR TABLE OF CONTENTS USE ONLY.}

High brightness and easy color modulation in lanthanide-based coordination polymers with 5-methoxy-isophthalate as ligand: Toward emission colors additive strategy

Insa Badiane, Stéphane Freslon, Yan Suffren, Carole Daiguebonne, Guillaume Calvez, Kevin Bernot, Magatte Camara and Olivier Guillou.

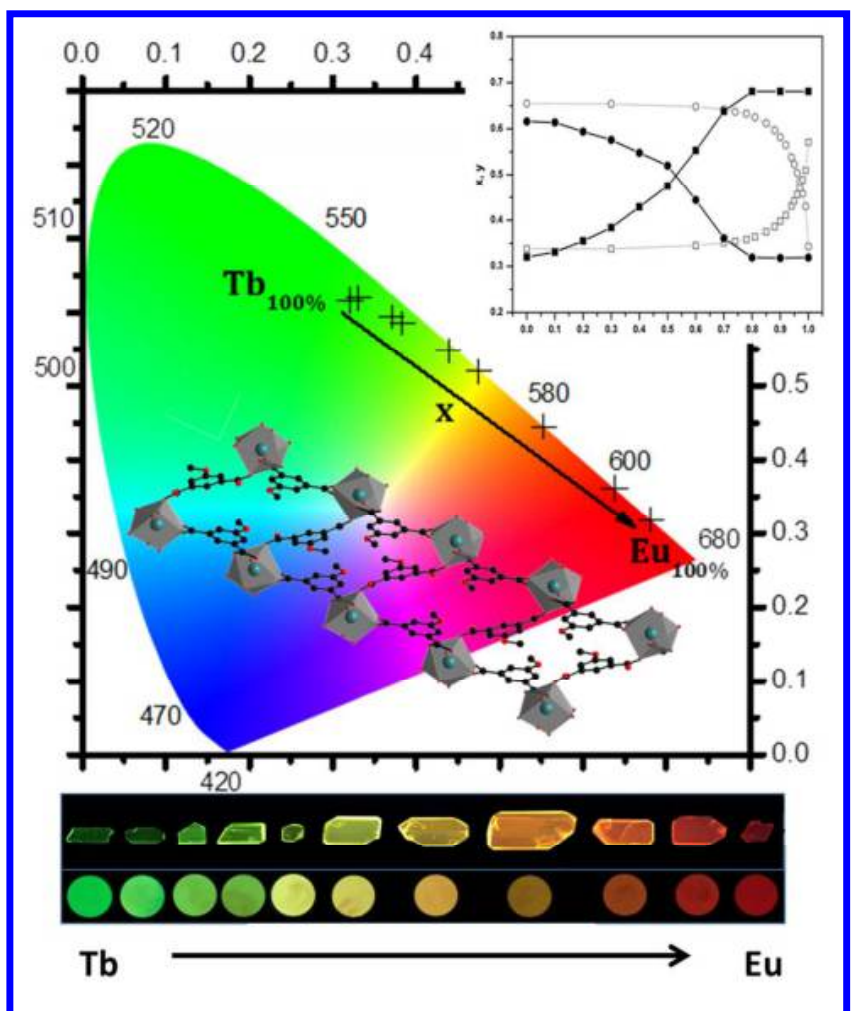

Some hetero-lanthanide-based coordination polymers with 5-methoxy-isophthalate as ligand present very weak intermetallic energy transfers and therefore exhibit original luminescence properties. 